\title{
The Cult of Itonia Athena and the Human Conscience
}

\author{
Eleni G. Goula \\ University of the Aegean, School of Social Sciences, Mytilene, GREECE \\ Department of History and Social Anthropology
}

Received: 1 December 2020 - Accepted: 29 December 2020 - Published Online: 30 December 2020

\begin{abstract}
The cult of Athena as Itonia is today almost completely unknown. Even in antiquity it was limited to specific areas as a local cult of the Aeolian tribe of the Boeotians, where, however, it had universal currency. Known places of her cult are in Thessaly, Boeotia and the island of Amorgos. At the Boeotian city of Koroneia, although the sanctuary of Itonia Athena is referring by the ancient writers (Pausanias and Strabo), its location has not been securely identified and the character of her cult is not well known. The available evidence (literary testimonies, mythological reports and archaeological data) suggest that her worship in Koroneia was a peculiar kind of mystery cult, which had accepted the influence of Orphism. This article highlights the properties of the forms involved in this secret cult and interpret the content of her worship in a philosophical context, with reference mainly to Aristotle's work "On Memory and Remembrance". The view supported by the present article is that her worship was oriented towards the achievement of selfawareness, to the Delphic oracular maxim "know thyself" ( $\gamma v \dot{\omega} \theta \mathrm{r}$ oavtóv). That was considered essential for the formation of the cultural consciousness of the societies of ancient Greece. This is a parameter of knowledge that in our modern societies has been forgotten, leading consequently to the misinterpretation of cultural development and a completely different perception of cultural memory and consciousness.
\end{abstract}

Keywords: Athena Itonia, Koroneia, mystic cults, self-consciousness, syneideses, memory, Aristotle.

1. Literary, mythological and archaeological indications of the cult

1.1 Cult regions of Itonia

According to the ancient literary tradition, sanctuaries of Itonia are known in Thessaly and Boeotian Koroneia (Figure 1). In ancient Athens, the well-known "Itoniai gates" in its walls that led to the port of Faliron, are considered to be associated with an undiscovered eponymous sanctuary. Inscriptions indicate another Itonia sanctuary on the island of Amorgos (Figure 1), which according to Marangou is located at "Psilos Trafos", on the road between the island's two cities, Arkesini and Minoa, which together worshiped Athena as Itonia (Graninger, 2010; Vaiopoulou, 2012; Lalonde 2019: 204-254).

(C) Authors. Terms and conditions of Creative Commons Attribution 4.0 International (CC BY-NC-SA) apply.

Correspondence: Eleni G. Goula (Phd candidate), University of the Aegean, School of Social Sciences, Department of History and Social Anthropology, Mytilene, GREECE. E-mail: elgoula@yahoo.gr. 
- Previous proposals about the location of the sanctuary of Itonia Athena in ancient Koroneia are examined in the view of recent researches in combination with archaeological evidence.

- Previous interpretations of the character of Itonias cult do not take into consideration all the beings involved in her mystery cult and the correlations between them. This is attempted in this article taking into consideration iconographic representations of the worship.

- Although theories of the Greek ancient philosophers are not usually used as interpretational tools for the content of ancient Greek mystery cults, this is attempted in this article. The Aristotelian theory about "Memory and Remembrance" is used as a guiding rule, in combination with platonic theories and orphic philosophy, in order to decrypt the cult myths associated with Itonia Athena worship.

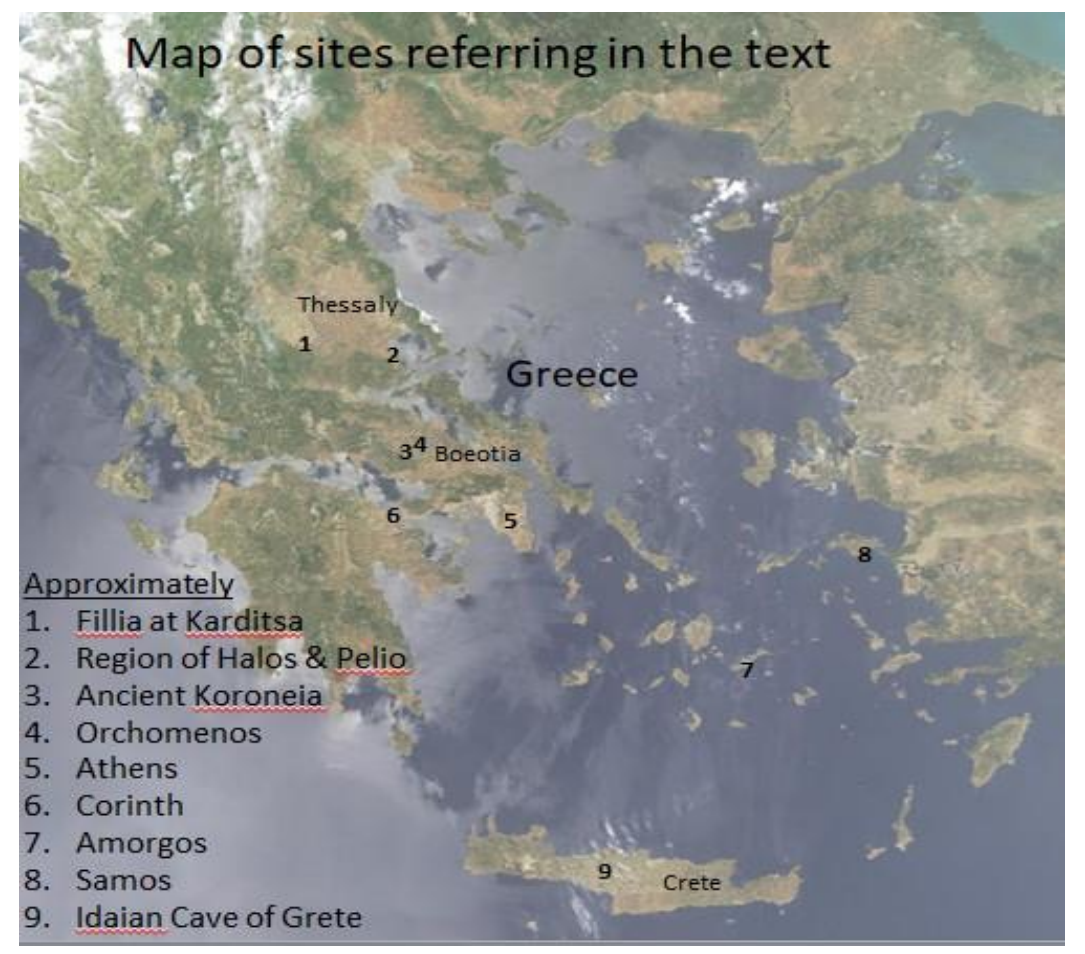

Figure 1.

In Thessaly it is argued (Vaiopoulou, 2012) that according to literary reports there should have been more than one sanctuary of Itonia. Excavations, however, have found only one, at Filia near Karditsa (Figure 1). It is considered to be the temple of Itonia mentioned by Strabo as being in the Thessalian city of Iton, on the river Kouralios. This is equated with today's river Sophodite, which flows into the river Pinios. Worship at the site is documented from the Early Geometric to the Late Roman period but until the archaic period ( $6^{\text {th }}$ century B.C.) it is thought to have been conducted in the open air in a grove, where offerings were hung on trees or other wooden structures. The sanctuary of Itonia at Filia is claimed to have been pan-Thessalian and from the $3^{\text {rd }}$ century B.C. is considered to have been federal. Ancient sources also report that in Thessaly both festivals, named "Itonia", and games were held in honor of the goddess. Moreover, there was a Thessalian month "Itonios" named in her honor, coinciding approximately with August. From ancient literary and epigraphic sources it can be concluded that Athena Itonia was a goddess and protector of all Thessalians (Graninger, 2010; Nikolaou, Vaiopoulou, 2012; Lalonde, 2019: 57-85). 


\subsection{The establishment of the cult of Itonia in Koroneia}

While I have briefly established that worship of Itonia Athena occurred in several places in ancient Greece, in this article I will focus on her worship in Koroneia in Boeotia. The main sources of information for the Boeotian cult of Itonia are the geographer Strabo ( $1^{\text {st }}$ century B.C) and the traveler Pausanias ( ${ }^{\text {nd }}$ century AD), who both visited her sanctuary (Strabo, 9.2.29, Pausanias, 9.34.1-2).

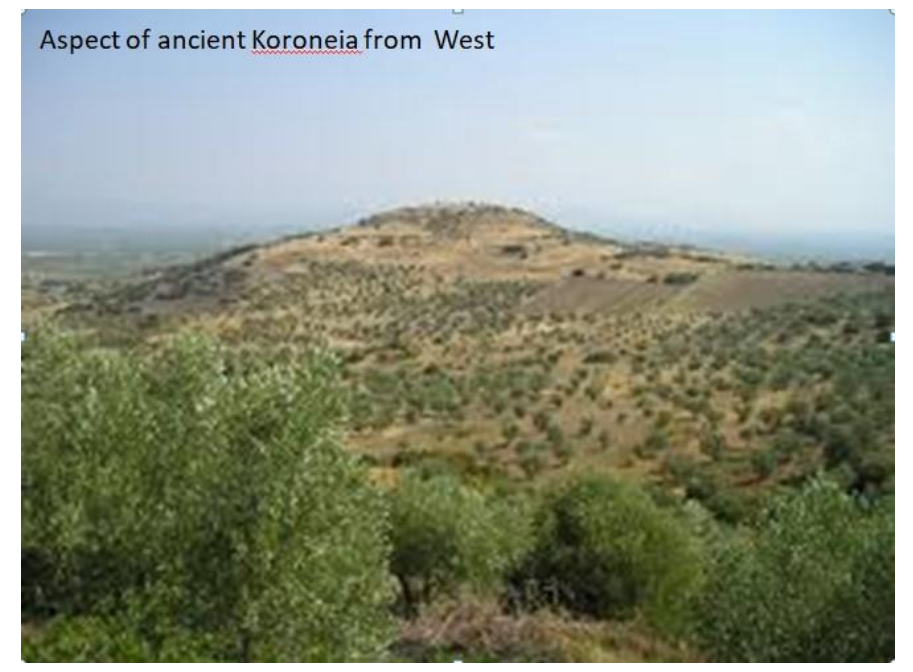

Figure 2.

According to these writers, ancient Koroneia was founded by Koronos, the brother of Aliartos. He, according to the myths, is considered either the son of Athamas, like many other settlers of Boeotia (Buck, 1979: 58), or the son of Thersander and grandson of Sisyphus (Christopoulos \& Kakridis, 1986, III: 121, 251). Other legends also link Koronos with Thessaly and claim him to be the son of Kaineas, king of the Lapiths, father of Leon and captain of a fleet of 22 ships (Polymeri, 2019: 388).

The first two myth variants connect the founder of Koroneia with the ancestors of Orchomenos and via them with the ancestors of the Greek tribe who come from a line linking back to Prometheus. Athamas, the king of Orchomenos, was the son of Aeolus and the grandson of Hellinas (who was the grandson of Prometheus), while Thersander, whom Athamas adopted, was his nephew. Through the legends, also, the region of Boeotia is connected with Thessaly and the Peloponnesus as well. Athamas, the legendary father of Frixos and Helle, is said to have come from, and reigned in, the Thessalian city of Halos (Buck, 1979: 58; Christopoulos \& Kakridis, 3, 1986: 100, 121), near which it is mentioned by ancient authors that there was one of the (unidentified) sanctuaries of Itonia on the river Kouarius (Graninger, 2010; Vaiopouloou, 2012). Sisyphus, on the other hand, was the legendary king of Corinth. He was the symbol of human destiny, because he revealed a divine secret and deceived Hades three times. He was therefore horribly punished, eternally carrying a stone to the top of a mountain, from where it rolled back down so he had to begin his struggle all over again (Christopoulos \& Kakridis, 1986, III: 117, 121, 124, 249-251, Lex. Myth: 279). From Corinth, the descendants of Sisyphus spread to the islands, even reaching Lycia in Asia Minor (Christopoulos \& Kakridis, 1986, III: 252). We cannot exclude the possibility of underlying hints in these traditions for the spread of the cult of Itonia as far as Amorgos.

The sanctuary of Koroneia was, like the Thessalian, pan-Boeotian and the center of the federation of the "Voiotikon Koinon" (Pausanias 9.34.1-2). From the $3^{\text {rd }}$ cent. B.C. emerges as a federal sanctuary of the Boeotians, being their national sanctuary (Schachter, 1981: 112, 119, 122). 
The cult of Itonia was brought by the Boeotians from the Thessalian city of Arne (Strabo, 9.2.29), when 60 years after the Trojan War (Thoukidides, A.12), they were expelled due to the intrusion of the Thessalian tribes. They settled near Orchomenos, which they controlled. Therefore it seems that the cult of Itonia was established in the Early Iron Age (Buck, 1979: 76-78). The mythical founder of it is said to have been Iton the son of Amphictyon (Pausanias, 9.34.1), whose name is reminiscent of "amphictyonies" (Burkert, 1993: 523), the tribal associations of cities, religious as well as political in character (Lalonde, 2019: 5-6, 138-9). The new sanctuary had the same name as the Thessalian (homonymon) and was created next to a river which also had the same name (homophonous) as the Thessalian one, Kouarios, or according to Alcaeus Koralios. There the great celebration of the Pamvoiotia (Strabo, 9.2.29) was held once a year, in the month of "Pamvoiotion" (September or October), with athletic games, horse races (hippikous agones) and music competitions, as we know from literary sources and epigraphic evidence (Schachter, 1981: 123-4; Lalonde, 2019: 151-165). In the museum of Thebes there are votive inscriptions of the classical period from the sanctuary, while others were found re-used, built into churches of the surrounding villages (Alalkomenes / Mamoura and Agios Dimitrios) (Papachatzis, 1992: 216). This was the open, public side of the worship of Itonia Athena.

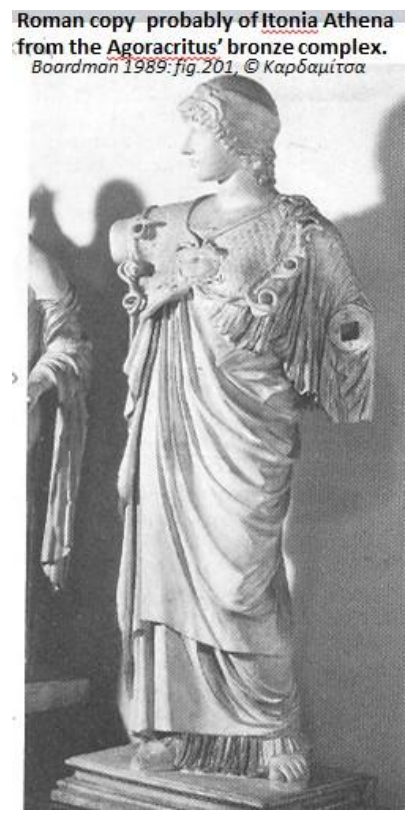

Figure 3.

But in Itonia's cult at Koroneia we have an element that is not mentioned for Thessaly, although we find it at Amorgos (IG XII 7.241, see Lalonde, 2019: 120, ft. 120). Itonia is coworshipped and her consort is Hades according to Strabo, or Zeus according to Pausanias. In other

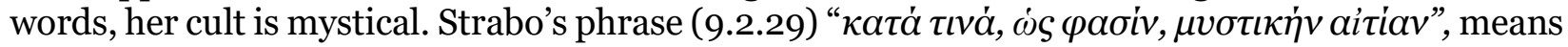
that there was a "sacred word". Lalonde (2019: 121-4, 126-131) misinterprets the meaning of Strabo's words and rejects, somewhat superficially in my opinion, the mystery, and consequently the chronic, side of the cult of Itonia Athena. Strabo's note "œ่ paoiv" indicates that he was not initiated into the secret worship of Itonia, and not, as Lalonde wrongfully concludes, that he did not personally visit the sanctuary and for that reason he had misunderstood the nature of her worship. On the contrary, the omission of the same phrase by Pausanias, who was objective and reliable according to Lalonde, rather indicates his initiation to Itonias' mystery cult. The "sacred word" ( $\mu v \sigma \tau \iota \kappa \eta v$ aitia $v$ ), was an unspeakable, secret, and it was communicated only to those who had been initiated, because only the initiates could understand the deeper meaning of her worship. According to it Athena was the mistress of the Underworld, companion of the chthonic Zeus- 
Hades. This is how the bronze cult statue that Pausanias (9.34.2) saw in the temple represented her, a work of the famous sculptor Agoracritus, student and collaborator of Pheidias in the Parthenon.

Most of the works attributed to Agoracritus have not survived, but copies have been preserved. One such Roman copy of a classical bronze statue, dating approximately to 430-420 B.C., is considered to be of Itonia Athena attributed to Agoracritus (Boardman, 1989: 201 (Athena Albani); Despinis, 1971), because of the unusual cap she wears on her head (Figure 3). This cap is

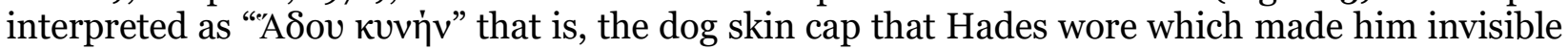
(eAc. Dic.).

\subsection{The location of the Itonion sanctuary in Koroneia}

The ancient city of Koroneia was located west of Lake Kopais, at the foot of Mount Helikon, on a hill surrounded by two rivers, Falaros and Kouarios (present-day Potza and Kakari respectively). The location of the ancient city has been identified (Leake, 1835) and investigated mainly by surface researches (Binliff et al., 2009; Bintliff et al., 2013; Farinetti, 2011) according to which there is uninterrupted occupation from $10^{\text {th }}$ century B.C. to $14^{\text {th }}$ century A.D.

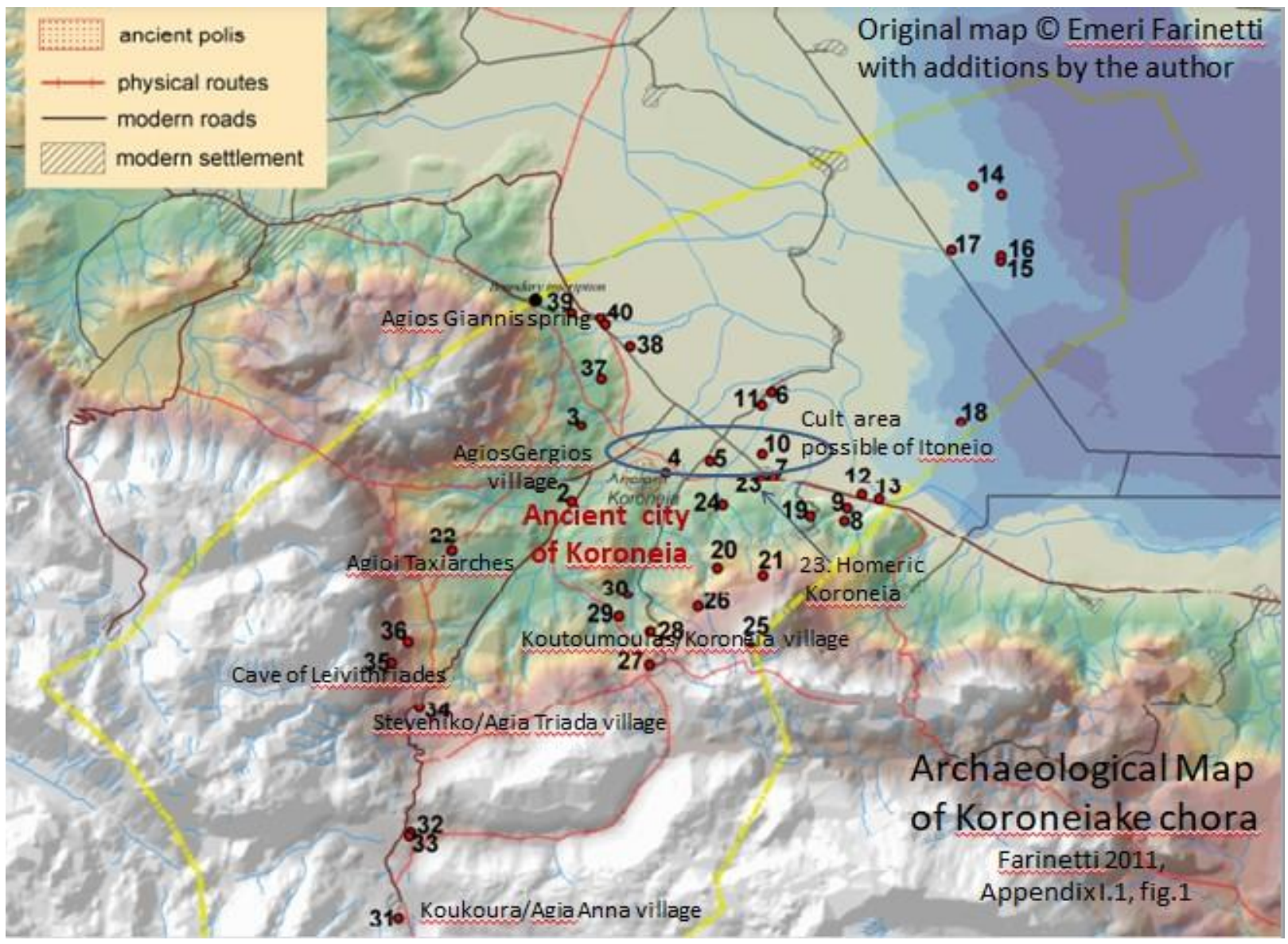

Figure 4 .

The location of Itonion, according to the topographic information of Strabo and Pausanias, was in a flat area in front of the city, which someone coming from the ancient settlement of Alalkomenae came to before reaching Koroneia's Agora. Various proposals have been made for the location of the sanctuary (Pritchett, 1969: 85-89; Spyropoulos, 1975; Fossey, 
1988: 330-332; Lauffer, 1986: 58) which are examined in detail by recent topographic archaeological research of the area (Farinetti, 2011: 5-9). The latest research data agree with the topographic indications of the ancient sources and conclude that the Pamvoiotion sanctuary of Itonia (Figure 4: no. 7, 10) occupied a very large area (no 10 estimated according to Lauffer at $700 \mathrm{~m}$ by $700 \mathrm{~m}$ ) at the entrance of the plain defined by the rivers Falaros and Kouarious North East of the hill of ancient Koroneia. In this wider area there are other places of worship (Figure 4: no. 4, 5) and one of them (no. 4) was excavated by Spyropoulos (Farinetti, 2011: 5-9). The huge area which the sanctuary is considered to have occupied is explicable by the needs of the Pamvoiotia festival. Moreover, we cannot rule out the case that the worship of Itonia in some periods was in the open air in a sacred grove, as in the case of the Thessalian sanctuary and the neighboring (Bonanno-Aravantou, 2008: 266; Papachatzis, 1992: 179-180, 201) ancient sanctuary of Poseidon Onchestos close to Aliartos.

\subsection{Archaeological evidence for the cult}

In the 1970s Spyropoulos (1972: 317; 1973: 285-392; 1975: 392-414; Papachatzis, 1992: 215-217), revealed three buildings in immediate proximity to each other, two of which were characterized as temples and one as a treasury. He located an extensive layer of the geometric period with evidence of burning on which the two temple buildings were built. The first (A) is dated in the archaic period, the other (B) to the 4th century BC, and both of them, after Roman repairs, were used until the late Roman period. On the floor of building A there was a geometric cremation pit containing a burnt cremation urn and grave offerings. According to the excavator, these buildings belong to the sanctuary of Itonia, which is considered to have occupied a large area (no. 4 of Figure 4 estimated as being $200 \mathrm{~m}$ on the North-South axis and $400 \mathrm{~m}$ on the East-West axis).

His view, however, has not been generally accepted (Fossey, 1988: 330-2), mainly due to the absence of epigraphic evidence, and one of the buildings he excavated has been proposed (Bonanno-Aravantinou, 2008: 265) as being either the temple of Hera mentioned by Pausanias (9.34.3) in the Agora of the city, or some important public building (see also Lalonde 2019: 108110, 130). However, as mentioned above, the latest research shows that Spyropoulos's excavation area is possibly part of the wider area that could contain the Itonio and is outside the city. In this case the cult buildings he excavated should be in close relation with the worship of Itonia. It cannot be ruled out that, in the wider cult area of Itonio, there were ancillary buildings for worship or other religious monuments and buildings relevant to the cult, such as the statues of Charites which show Pausanias. In this case, and having in mind that ancient Greeks used to respect their ancestors and not disturb earlier burials, the cremation pit with the burnt urn in the floor of building A, which Spyropoulos excavated, could possibly be associated with hero worship such as that of Koronos, the founder of the city, or even lodama. In both cases it could logically be combined with the worship of Itonia and integrated in her sanctuary. Koronos' worship is known epigraphically (I.G. VII 2873.), as well as the cults of Thesmophoros Demeter (IG VII 2874-2876), Dioscuri and the Egyptian deities Sarapis, Isis and Anubis (Papadakis, 1916: 220; Fossey 1988: 328 ), but the location of their shrines has not been identified. However, the verification of this hypothesis would be possible only after the complete publication of the excavation data and the continuation of the investigation. While Spyropoulos' limited excavation remains incomplete and the excavation material not fully published, we can't form a more complete picture of the cult.

The epigraphic material, although scattered, gives us enough information about the "panygeres", the festival of Pamvoiotia (Schachter, 1981: 122-3; Lalonde, 2019: 151-165), but it is not very enlightening about the mystic worship of Itonia. An inscription of the $3^{\text {rd }}$ century A.D. mentions the animals sacrificed to the goddess certifying its chthonic character (Spyropoulos, 
1975: 410; Despinis, 1971: 145), but in general the archaeological data are rather poor on this issue, except for a few depictions of worship.

\subsection{Representations of worship}

Regarding the nature of worship of Itonia, we draw some evidence from a few iconographic representations. A small clay seal from Roman times, found in Spyropoulos's excavation (1975: 408-9, no image available) with a representation of a female figure is an important example. She is wearing a three-plumed helmet and is framed by two snakes. In the background a plant design links with the top of her head. The figure is considered to be Itonia Athena as she was represented to the Agoracritus complex. By Spyropoulos were also found two Hermetic columns, one of which bears the inscription "Nike" (Spyropoulos, 1975: pl. 295). On a black-figured vessel of the $6^{\text {th }}$ century B.C. at the Louvre, we see a warlike Athena, surrounded by snake heads, addressing Hermes (Louvre, CA 1446). A black figured lekanis in the British Museum (B80), dated circa to 550 B.C., depicts (Figure 5) a bull sacrifice procession to a burning altar on which a bird stands. Athena as Promachos and the serpent which is depicted behind her, stand between the altar and a pillar (British Museum Reg. Num. 1879, 1004, 1, LIMC ad. 42439, Lalonde, 2019: 127). The pillar is often considered as a symbol of a temple, and in many cases indicates the Great Goddess of Mother Earth (Goula, 2012). The innterior scene of lekanis B8o (Figure 7) is probably associated with initiation ceremonies. It depicts three figures. On the left a tall naked man leaning to the right stands calmly holding by the arm a smaller sized dressed figure - which wears a cap. This figure has a raised sword threating the tall standing man and runs to the right with another naked male figure. The two running figures have their faces turned backwards looking at the standing tall man, behind whom a plant branch is depicted, obviously indicating that the ceremony takes place in an open space, in nature.

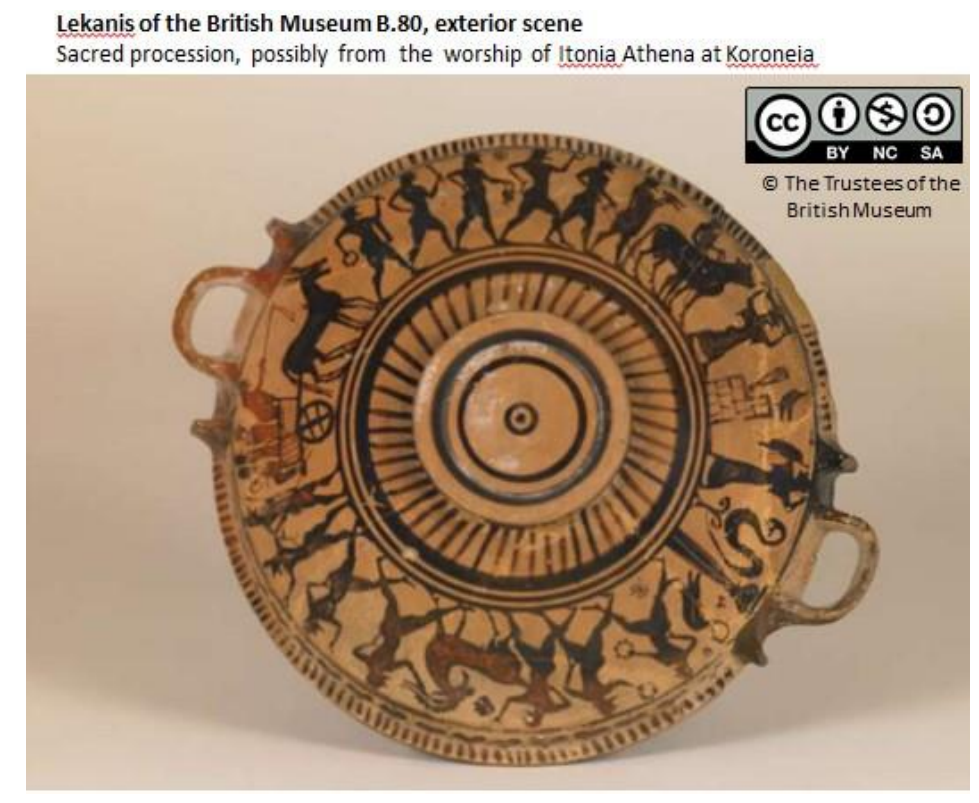

Figure 5 .

In a representation of a ring stone in Florence (Figure 6), Athena is depicted as the Lady (Despoina) of the Underworld, standing near an altar and having next to her the chthonic Zeus-Hades, at whose feet stands the three-headed Cerberus, the terrible dog that guarded the doors of Hades (Christou, 2002: 11, 13; Christopoulos \& Kakridis, 1986, I: 230; Lalonde, 2019: 130 $\mathrm{ft}$. 171). The altar is associated with Iodama. She, according to Pausanias (Paus. 9.34.2), is the priestess of Itonia Athena and invaded the sacred precinct (temenos) of the Goddess at night. She 
suddenly saw the head of the Gorgon Medusa embroidered in the tunic (chiton) of the goddess and was turned to stone. She was transformed into an altar, on which an inextinguishable fire burned. This was to be maintained every day by a woman who, at the time of rekindling it, shouted three times in the Boeotian dialect that "Iodama lived and asked for fire". This figure is symbolized by the altar on the Florentine ring stone and on the lekanis of the British Museum B8o.

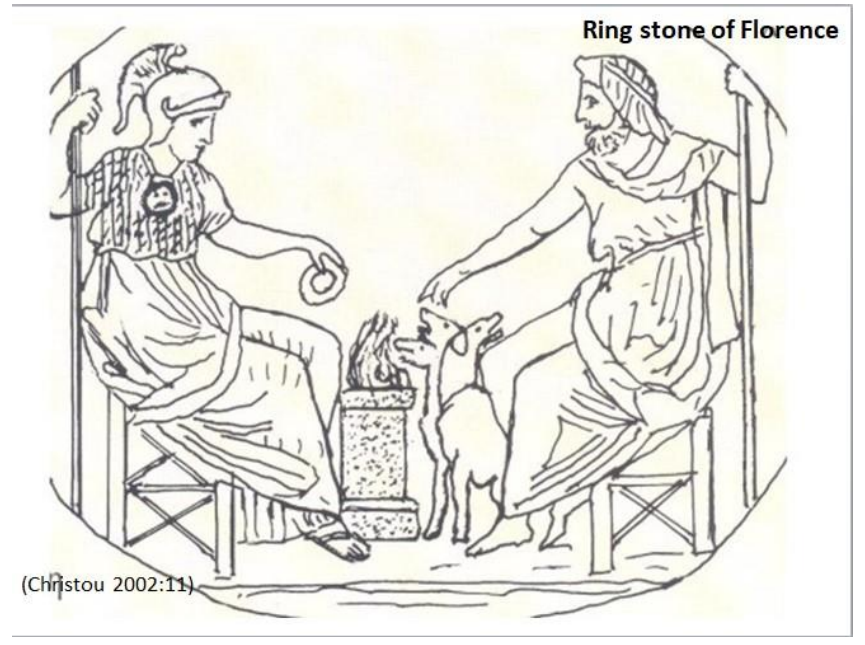

Figure 6.

Cerberus connects Itonia with another cult that is reported in the area of Koroneia, that of Herakles Haropos (Paus. 9.34.5), or Charops, Palaimon or Kallinikos (Papachatzis, 1992: 215, 216-7, 219-220). At the source of the holy river Falaros, according to a local legend mentioned by Pausanias, Herakles raised Cerberus from the underworld. The sanctuary is also known from more than 15 slave emancipation inscriptions of the 3 rd and 2nd century B.C. -most of them engraved on a pair of door pillasters (parastadhes) which possibly come from the sanctuary- that have been built into churches in the surrounding area (Papadakis, 1916; Schachter, 1986; $7 \mathrm{ft} .3$; Papachatzis, 1992: 218-220). The freed slave was dedicated with an oath to Herakles Charops, and in most of the emancipation decrees the priestess acted as guarantor. Both the oath and the unusual element - for the cult of Heracles - of the priestess, are associated with local traditions. The deity is referred to as a child or adolescent (youth) and the priestess may represent a surrogate mother or nurturer. The name "Charops" or "Charopas" is documented from the $6^{\text {th }}$ century B.C., but we find it also in later inscriptions from Thespiae and Thisbe, which are considered to be associated with the worship of Herakles, although this is not confirmed epigraphically as in Koroneia. It is claimed that in Boeotia there was a tradition to worship the birth and youth of Herakles. Especially on Mount Elikonas is considered to be honored as a young hero hunter, who merged with and absorbed the local hero Aktaion, the one who was devoured by his dogs. He was brought back to life by the centaur Chiron making his image in his cave (Schachter, 1986:10-11).

The snake, which we have in the above three representations is considered as a symbol of the inevitable cycle of life (Schuré, 2016: 243). It has also been claimed that in the worship of Itonia it indicates the chthonic Zeus-Hades. It is assumed that it was represented initially as serpentine and only when the Itonion became a federal sanctuary it named Zeus Karaios/ Akraios, and possibly Agoracritus was the first who depicted it anthropomorphically (Schachter, 1981: 120121; 1994: 104-106).

Chtonios Zeus in the worship of Itonia is considered a more refined form of Lafistios Zeus, a name that means "devourer", whose worship is also found in Thessalian Halos (Papachatzis, 1992: 219; Schachter, 1994: 104-6, Lalonde, 2019: 127). In his shrine Athamas tried to sacrifice his children Frixos and Elle, who were finally saved by flying away with the golden ram, which is considered (Cook, 1964, I: 403-5) to symbolize the bliss (eudaimonia) of a ruler, the sun, 
as well as soul. It has been argued that the areas of Boeotian Koroneia and Thessaltan Halos shared the same type of worship of Zeus, in which the god has two distinct but opposite sides, as overlord of the sky and of the underworld. To his first quality, as ruler of the mountain peaks, corresponds his cult epithet "Karaios / Akraios" with which Zeus was widely worshiped in Boeotia (Schachter, 1986: 104-6).

In Koroneia, probably the feast of "Akraia", which is testified in an emancipation inscription with an oath to Herakles Charops, was celebrated in honor of Akraios Zeus. It is speculated that during this feast, which probably took place in the middle of summer or as part of Pamvoiotia, there was a ritual procession, perhaps to the top of Mount Lafistio, and possibly this procession is represented in the vase of the British Museum B80. In relation to the worship of Akraios Zeus in Pelion, where the god shared his shrine with the chthonic Chiron, it is claimed that in Koroneia, at least from the $5^{\text {th }}$ century B.C., Zeus, as Lafistios and Akraios, was coworshiped with Herakles Charops sharing the same sanctuary, which should also have had a cave in addition to the temple (Schachter, 1994: 104-108).

The location of the sanctuary has not been identified epigraphically, but it has been suggested that it may have been located either at the Monastery of Agios Ioannis (Papadakis, 1916, Schachter, 1986: 10-116) at the foot of Mount Lafistios (Figure 4, no. 39) or at the chapel of Agioi Taxiarches (Papachatzis, 1992: 219-220; Spyropoulos, 1972; Papadopoulos, 2010) at the foot of the hill on which Koroneia stood, in the place where the source of the river Potza rises (Figure 4, no. 22). In both places there are springs with abundant running water, which could be associated with the mouth of the underworld. Recent archaeological research (Farinetti, 2011: 16-18) has shown that cult activity is not documented in the first of these two places and the second option is more likely for a shrine of Herakles Charops.

In this place (no. 22 of Figure 4), a few meters from the source of the holy Phalaros, the post medieval church of Agioi Taxiarches, built incorporating ancient inscriptions, is considered (Papachatzis, 1992: 219-20) to have probably occupied the site of an ancient temple of Charops. Also, in that place has been excavated a Roman portico, a standard feature in a sanctuary (Spyropoulos, 1972: 316), and an inscription from the imperial period (IG VII 2882) referring specifically to the city of Koroneia has been found (Fossey, 1988: 329). Finally, the spatial proximity of Agioi Taxiarches to the cult place of Itonio makes the correlation of the two cults feasible, so as to explain the depiction of Cerberus together with Itonia and Zeus-Hades on the ring stone in Florence. The site, which is at a distance from ancient Koroneia of about 4 kilometers corresponding to the 20 stadia mentioned by Pausanias for the distance of the sanctuary of Laphystios Zeus, is located between Mount Livithrion and Laphystion, at the foot of the latter. Therefore, the sacral procession of the B.80 vase, which may represent the feast of "Akraia", should probably be assumed to have followed a route from the sanctuary of Itonia Athena to that of Laphystios Zeus, who probably was co-worshipped with Charops Herakles in the same temenos.

In the neighboring village of Agios Georgios, has been found, incorporated in the old church of Agios Ioannis, a dedication inscription (IG VII 2874) to Herakles Palaimon (Papachatzis, 1992: 218). This cult epithet of Herakles is found in several literary sources, but also in his Pangrateion sanctuary on the banks of the Ilissos river. The figure Pangratis, depicted as a head emerging from the ground, was a chthonic deity, who was probably identified with the Coroneian Charops Herakles and both shared the epithet "Palaimon" (Schachter, 1986: 10-11).

Therefore, six beings are associated with the mystical cult in Itonio: Itonia, Iodama, Zeus-Hades, Herakles, Cerberus and the Gorgon Medusa, because of the magical properties of her image. To understand the content of this sacramental worship, then, we must decode the symbolism of these forms and the relationship between them. 


\subsection{Given interpretations for Itonia}

As discussed, Pausanias attributes the establishment of the cult of Itonia to Itonos, but without dealing with its origin and the etymology of the name of the goddess. According to a tradition, the cult epithet "Itonia" indicates the Thessalian origin of Athena. She was named after her father Iton, the son of Amfiktion (grandson of Deucalion), and came from the Thessalian city of Iton, the third oldest city in Greece (Vaiopoulou, 2012: 154, Lalonde, 2019: 22-23). This tradition is based on Byzantine sources of the $12^{\text {th }}$ century (Tzetzou comments on Lycophrnon, 1811: 554-5) and the 15 ${ }^{\text {th }}$ century (Etymologicum Magnum, 1499: 239 col. 480) which preserve older mythical narratives of genealogist Simonides and Apollonius Rhodius. According to this tradition, Iton had two daughters, Athena and Iodama, who got involved in a battle and Athena (Itonia) killed Iodama (Kerenyi, 1966: 122; Wikipedia: Itonia). The source of this mythical tradition, as Apollonius Rhodius (1.551a) himself informs us, is the book of ancient author Armenidas, "Thevaika", which means stories about Thebes.

According to the prevailing view, Itonia, the cult of which the Boeotians brought from Thessaly, is consider to be a pre-Hellenic local deity of the Bronze Age who later merged with the Olympic deity of Athena, but was not completely absorbed by it. Itonia Athena as a goddess of vegetation and nature sent people the fruits of the earth, like Hades by the name of Pluto. Iodama, the figure who accompanies Itonia, is also considered to be a personification of the vegetation, as well as the goddesses Charites (Graces), whose statues were erected in the sanctuary in Koroneia during the time of Pausanias (Christopoulos \& Kakridis, 1986, I: 230-231, II: 105, III: 216; Vaiopoulou, 2012; Spyropoulos, 1975; Wikipedia Itonia).

Most scholars recognize that the fertility and the martial quality of Itonia are combined, but some argue that the latter is dominant (Papadakis, 2012; Lalonde, 2019: 86-87, 131-2). Her warlike nature is emphasized in poetry of the $6^{\text {th }}$ and $5^{\text {th }}$ century B.C. Alkaios describes

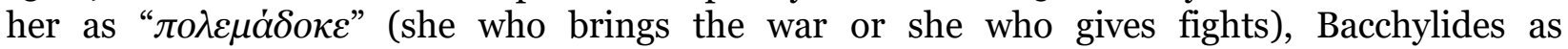

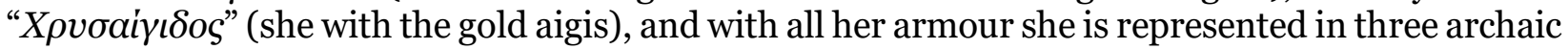
vessels. Athena Itonia is considered as the protector of warriors (Schachter, 1981: 118-119). Also, the etymology of the name "Itonia" is considered to refer to warfare, as the word " $\tau \omega \nu$ " - from the verb "عiٓu" which means go and come - is translated as aggressive, adventurous. Therefore, as a goddess of war, she fed Hades with the dead (Papachatzis, 1992: 217-8).

Spyropoulos (1975) is categorically opposed to the consideration that the main character of Boeotian Itonia is warlike. Relying on the representation of the small Roman clay seal, as well as on other related elements of the surrounding area (mouth of Hades at Charopeio, cult of Demeter Thesmoforos), he claims that her cult is related to a deity of vegetation, of life and death. Her chthonic and mystic character bears similarities to the cult of Demeter and Kore, but over time merged with the qualities of Athena Promachos. Many scholars recognize analogies between Persephone and Iodama who fell asleep in the winter months waiting for the fire to light in the spring in order to come to life again, and the parallel between the worship of Itonia and the mystical worship of Eleusinian Demeter has not been disputed (Christou, 2002: 12-13; Christopoulos \& Kakridis, I: 230-231, III: 216. Vaiopoulou, 2012; Yovi, 2017). Only Lalonde (2019: 126-131) categorically rejects all views on the chthonic character of Itonia Athena in Koroneia, because he considers them to be contradictory and inconsistent with the warlike character of the Thessalian goddess introduced to Boeotia, as he tries to substantiate.

Nevertheless, water and vegetation, often associated with chthonic deities, are considered to be the two main elements of the worship of Itonia Athena in both Thessaly and Boeotia. In both areas the sanctuaries were next to rivers bearing the same name (Kouarios), and at least in Thessaly it is confirmed that they were in a sacred grove (alsos). Because of this, Ileana Chirassi has suggested that the name "Itonia" comes from "Itea", meaning the willow tree (itia) found beside of water, thus denoting Athena "of the Iteon" or "of the Iteona" (Vaiopoulou 2012). 
The name of the river Kouarios is also considered to come from the word "kouri" (= daughter) or "koura" and has been associated with coming of - age - ceremonies (rites of passages), during which young men and women dedicated their hair to the goddess (Spyropoulos, 1975; Vaiopoulou, 2012).

Vaiopoulou considers Itonia as a Thessalian deity, or more correctly as a general type of Mediterranean vegetation deity, which at some point passed through Thessaly, matched the myths and traditions there and from there spread to Boeotia and Attica. She observes that Itonia is primarly a wider Mediterranean deity, rather than a local or even purely Greek one, who took on some of the characteristics of Athena when she entered mainland Greece from Crete (Vaiopoulou, 2012). On the contrary, according to Spyropoulos (1975) the chthonic character of the mystical cult of Itonia is purely Boeotian and dates back to the Minoan past. It should be noted that the title "Thevaika", which is the source of the "Thessalian" version of the myth, leads us to the cycle of Boeotian myths. It is also worth noting that behind Deucalion hides his father Prometheus. It was who deceived the gods and stole the art of Hephaestus and the wisdom of Athena to give them to humans, who were in danger of extinction (Plato, Protagoras), and finally the origin of Itonia, Iodama and Koronos goes back to him.

From what has been displayed so far, two main questions arise regarding the mystical cult of Itonia: the origin of her cult and the character of the main deities, as well as the beings that accompany them, which as we have seen are not considered in combination. In this article we will focus on the second issue concerning the content of her sacramental worship.

\section{Interpreting the cult}

In order to understand the mystery character of the worship of Itonia, perhaps the myths and philosophy reveal more to us than the literary testimonies and archaeological data.

The interpretations given to the qualities of the deity focus mainly on Itonia's relationship with Iodama without placing emphasis on the mysterious character of the worship. Nor do they consider the role of other figures: The Gorgon Medusa, Zeus-Hades, and Cerberus who is associated with Heracles. In order to understand the relationship of these figures, to decode the symbolisms and to interpret the character of this mysterious local cult, I consider the contribution of ancient Greek philosophers, mainly Aristotle, to be especially useful.

\subsection{The interpreting frame according to the Aristotle's theory}

Aristotle's treatise "On Memory and Remembrance”, from his book "Metaphysics", examines the relationship between memory and conscience and explains that memory contributes to the conquest of "knowing oneself". Although this text has been translated and commented on by English speakers (Sorabji, 1972; Bloch, 2007; King, 2009), I have chosen to rely on the translation and interpretation given by G. Charalampidis (2018), because I believe that his interpretation helps us better to understand the cult background that concerns us. Besides, the mystical cults in ancient Greece were "sacred tales" that applied, on a ritual level, the philosophical worldview of the time, and Orphism is considered (Schuré, 2016: 225-7) to have played an important role in this connection between ritual and philosophy.

Aristotle distinguishes two types of memory that both fall under the domain of Mnemosyne (Memory, Remembrance), the mythical daughter of Heaven and Earth with whom Zeus coupled and gave birth to the Muses. They were worshiped on the sacred mountain of Helikon as guardians of civilization (of epic, tragedy, lyric poetry, music, dance, history, astronomy). According to Strabo (59.9.2.25/C410) the Thracians brought the worship of the 
Muses on Helikon, which is another aspect of the Orphic worship that we know (Platritis, 2017) was particularly widespread in Boeotia from the $6^{\text {th }}$ century B.C. onwards.

According to Aristotle, humans have two types of memory: simple mental Memory ( $\mu \varepsilon \dot{\varepsilon} \mu \eta \sigma \theta \alpha \iota)$, and Remembrance/ Anamneses, the memory of the soul ( $\dot{\alpha} v \alpha \mu \mu \nu \eta \dot{\eta} \sigma \kappa \varepsilon \sigma \theta \alpha \iota)$. Simple memory is a process that concerns the Mind, which is based in the brain, and has to do with the process of accumulating and storing knowledge and the experiences of our daily lives. On the other hand, the function of Anamneses is a process that concerns the soul, which is based on the heart and concerns the memories from our previous lives, that is, it characterizes the possibility of retrieving our prenatal knowledge through mental processes. Simple memory, which involves the accumulation and processing of information and knowledge, works at a relatively slow pace in the

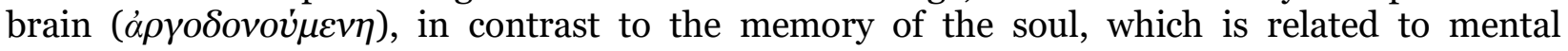
cultivation and therefore works faster ( $\tau \alpha \chi v \delta o v o v \mu \varepsilon v \eta)$. Those who deal with the latter, the "memorabilia" ( $\dot{\alpha} \alpha \mu \nu \eta \sigma \tau \iota \kappa o i)$, in contrast to the "mnemonic" ( $\mu \nu \eta \mu o v \iota \kappa o i)$, increase the speed of operation of their Remembrance/Anamneses, become quick-witted, and gain the opportunity to evolve more and more, because they begin to realize their divine origin (Charalampidis, 2018).

In other words, these are two different qualities of memory, whose natural control instruments are found in the human body. The mental memory is controlled by the Mind - Zeus, which is located in the brain and is manifested by electricity, whose symbol is the thunderbolt of Jove, while the mental memory is controlled by the Hera-Soul, which rests on the heart and is manifested by magnetism, which is considered to symbolize the liquid element of water. These two qualities of memory, which correspond in modern terms to emotional intelligence (EQ) and mental intelligence (IQ), complement each other, but they do not always work together, because their function is bipolar, that is, when one pole works, the other is switched off, and vice versa. The two forms of memory have parallel and unconnected functions. As a result, a fundamental bipolar division prevails in the internal mode of operation of the human hypostasis (the underlying state or underlying substance which is the fundamental reality that supports all else). Due to the disconnected function of the two poles of memory, an inner conflict is created in humans between emotions (heart) and logic (mind). As a result, the person who works in this way is constantly in a chaotic and indecisive state, in a constant inner turmoil and conflict. This division of the individual's personality does not allow its development, and additionally can cause serious psychosomatic problems (Charalampidis, 2018).

This Aristotelian theory is also substantiated by modern scientific research (Vythoulka-Muresanu, 2014) which identifies two types of "syneideses" that interact with each other in order to form a single coherent system that governs our experience and decision-making process, the operating mode of which has a decisive impact on human health. One concerns the awareness of the environment and is defined as "consciousness" or "consciousness of information" (see Liddell \& Scott, 1994: 1704), while the other is used in the moral sense and is defined as "conscience" (an inner feeling or voice viewed as acting as a guide to the rightness or wrongness of one's behavior). In the present article we adopt the aforementioned differentiation of two meanings for the Greek word "syneideses". The latter is considered to have a decisive effect on humans' emotional and mental balance, and it is found that many psychosomatic problems are caused when it is low or non-functional. That is what Aristotle identifies as the disconnection of the mental and psychic memory. However, for modern science it remains a key issue to discuss and investigate whether conscience is within the brain, whether it is just the result of a chemical compound, or whether it is beyond the structure of the brain in a transcendental state. For Aristotle this question had been answered.

According to Aristotle, because these two poles of memory are part of a system, their cooperation and collaboration is not only not impossible, on the contrary it is the desirable goal. This is because the harmonization of Mind and Soul, logic and emotion, will allow the fully conscious function of our brain and will make possible the knowledge of oneself ( $\gamma v \dot{\omega} \theta \iota \sigma \alpha v \tau o ́ v)$, 
that is, the knowledge of the human soul and the human destination. This was the main goal of ancient Greek philosophy and the secret initiation rites. This is achieved by a process that Aristotle

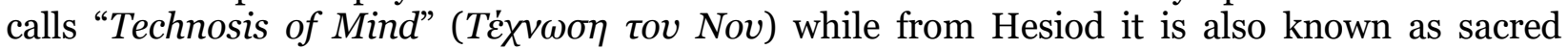
marriage (Hieros Gamos) (Charalampidis, 2018).

\subsection{Zeus-Hades}

In the sanctuary of Itonia is worshiped the Hieros Gamos of goddess with Zeus-Hades, while her birth is celebrated in the neighboring sanctuary of Athena Alalkomenia (Kerenyi, 1966: 122; Christopoulos \& Kakridis, 1986, II: 101; Schachter 1981: 111-113), to which Itonia seems to be connected and identified. These two elements, birth and Hieros Gamos of a goddess, in some cults are combined in the same sanctuary, as in the Heraion of Samos (Figure 1) (Tsakos \& ViglakiSofianou, 2012: 69). A common structural element of the two cults of Athena is the presence of a river beside which the two sanctuaries are located. Water is considered (Charalampidis, 2018) to symbolize the unstructured soul that carries its incurable wounds (tylefeia traumata). Through this element, however, the transition from the state of unconsciousness to one of consciousness will take place.

In the cult of Itonia her consort, Zeus-Hades, has been associated with the Orphic cult (Vaiopoulou, 2012), which is known to be of Thracian origin. We learn from Strabo (9.2.4/ C.4012, 9.2.25/C410) that a Thracian tribe, the Pierians, had inhabited Boeotia and had spread the cult of the Muses and the Livithrian Nymphs, but were later expelled by the Boeotians. With the Thracian cult Strabo associates the sanctuary of the Muses on Helikon, the fountain of the Horse (Hippokrene) and the cave of the Livithridiadian Nymphs. This last one, according to Pausanias (9.34.4) was on Mount Livithrio, 40 stadia distance from Koroneia, and there were two springs in the shape of a female breast, the Livithriada and the Petra. According to this, Papachatzis (1992: 181a, 219a) has deduced that Thracian tribes had inhabited Mount Livithrio, which is identified with the slopes of Helikon that rise above ancient Koroneia and the chthonic cult of Itonia Athena. Also, as can be deduced (Cook, 1964) from Nonnos' reports, the Orphic tradition is probably traced to Thebes, where the Kabeiria (Goula, 2012; Schachter, 2003) were also present.

In the Orphic myth (Orf. Frag., 41, 47) Orpheus is identified with Zeus, who dies and is reborn as Zagreas. This rebirth takes place through two successive congresses of Zeus in the form of a serpent: first with his mother Rhea or Demeter and then with the fruit of this union, his monstrous progeny Persephone, a horned child with two faces and four eyes, two in the normal position and two on her rear face. From this union was born the chthonic Dionysus or Zagreas. He is represented (Nonn. Dion., 6, 155ff) as a baby with horns, who took over the throne of Zeus himself and sat on it, taking the thunderbolt in his tiny hands. The attack of the Titans follows, which was motivated by Hera. With their faces smeared with plaster, they attack Dionysus when he looks at himself in the mirror. Dionysus tries to escape them through successive metamorphoses: he took the form of the young Zeus who brandished the Aegis, the old Kronos who made rain to fall, a shape-changing baby, a fierce youth (Kouros), a lion, a horse, a snake with horns, a tiger and a bull. In this final transformation he was cut by the knives of the Titans. The ram, the bull, the snake and the lion are also combined in the face of Orphic Fanis (Cook, 1964, I: 398-401).

The Orphic Zeus is also considered to be worshiped as a sun-god, based on the analogies with Sabazios in Thracian-Phrygian worship and with Ammon in Egypt, with whom they seem to be identified. Common elements are recognizable: the snake, the sacred oak tree, the consort (paredros) wife associated with Mother Earth. It is also claimed that these two cults influenced the Cretan cult of Idaios Zeus, in whose name sacraments were performed in the Idean Cave where Pythagoras was initiated (Cook, 1964, I: 400-403, 645-650). After he had been purified he descended into the Idean Cave three times, where he stayed for 9 days each time, 
offered a sacrifice to the dead Zeus and saw his throne. He also left an epigram entitled "Pythagoras to Zeus" which begins with the strange phrase "here lieth the dead Zan, whom humans call Zeus" (Porph. v. Pyth., 17). According to Cook, the throne was prepared for the dead Zeus who would be coming back to life, and Dionysos Zagreus is in a sense the reborn Zeus (Cook, 1964, I: 646, ft. 3).

This strange connection between "Zen" and "Zeus" could possibly be explained if "Zen" be associated with "Zan", which is considered to be a Doric expression of an older Zeus, comparable to Ianos, whose cult is clearly traced in Crete (Cook, 1965, II: 341-344, ft. 3). The connection of Zen-Zeus is also found (in presocratic philosophers and especially in Heraclitus. "Zen" is considered to mean the cosmic substance described by various names, such as Creative Fire, Aether and Zeus. Thales the Milesian stated that all things are full of god and have life and the Stoics established that it is encountered to a greater or lesser degree in all things (Cook, 1964, I: 29-31; Danezis-Theodosiou, 2013), something that has been documented by today's astrophysics (Danezis 2017a). The pseudo-Hippocratic work "On Diet" states: "all things are the

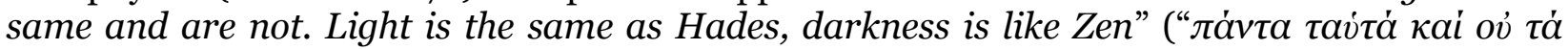

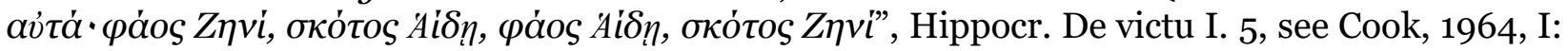
$29 \mathrm{ft} .1$ ).

Consequently, according to ancient Greek philosophy and Orphic mythology, all things and situations have two aspects that seem opposites (such as the Orphic Persephone with two faces, such as Itonia and Iodama, such as the celestial and the chthonic Zeus of Koroneia). The cosmic substance, which is represented by Zeus, can be regenerated through death. Zeus is the cosmic (sympandikos) mind, Zagreus the renewed form of this universal substance through death, the recycling of life. Perhaps we could compare Zagreus with the human soul that has come in contact with the universal substance.

"The human Soul came from the Divine Mind. Part of it, as it mixes with the passions of matter, is altered, but another wonderful part of it holds our head high, so that we can breathe the fresh air, like an airway of communications with the scuba of someone who has dived to the bottom. The part that is in the underwater body is called the Soul. However, for what is not altered, many, seeing it as a reflection on a mirror (esoptron), believe that it is inside them. But those who sense correctly know that this is outside of them and call it a Daemon." (Plutarch, On Soctrates' Daimonium, 590B)

Itonia as the consort (paredros) of Zeus is an aspect of Mother Earth who knows the secrets of world creation and the final destination of human souls. According to Plato (Politeia, I. $614 \mathrm{~b}$ ), when human souls die and until their judgment - whether they will be reincarnated or whether they will go to higher levels - remain in her palaces, in the sacred meadows (leimones) of Persephone (Charalampidis, 2019: 58, 61-2).

The snakes which we see surrounding her in the clay seal from Koroneia, possibly indicate her union with Zeus-Hades, while the floral motif, in which she seems to be floating, refers to the sacred tree of life, to the cosmic essence, in Zen. This, as depicted, is united with the divine figure through the intellect of the brain, which itself is protected by the helmet with the three plumes. Therefore, the power of the Itonia-Zeus couple is not limited to nature alone, but it also has the power consciously to transform a person, and this is achieved through the processes of memory.

According to Aristotle, the Meditation process, through which the Technosis of the Mind is achieved, has to do with the position of the Sun and is an electrical process, in opposition to dreams, which have to do with the position of the moon and are a magnetic process. (Charalampidis, 2018). We can assume that the same was true for self-knowledge, through the initiation rites of the Holy Marriage (Hieros Gamos). This explains why in Orphic worship Zeus was identified with the Sun. However, it is worth noting that in the oracle of the neighboring 
Trophonius, which was "autophono", meaning that the answer was given by the god himself, (Papachatzis, 1992: 236-241; Bonnescere, 2003; Varouxi-Badila, 2010) it seems that electricity played a role in both the oracle's prophesy and the therapeutic procedures (Platritis, 2017). There, as is inferred from the descriptions of ancient sources (Schachter, 1994: 68-89), especially of Pausanias (9.39.5-11), the process of oracular prophesy is a process of gaining knowledge of oneself through death and rebirth, to which the initiate is led by uniting the memory of the mind with the memory of the soul.

Aristotle in his Metaphysics believes that of the three basic substances which are responsible for the creation of the universe, the Mind of Zeus is the original substance that acts and moves the other two, he Continuous Essence ( $\Sigma v v \varepsilon \chi \dot{\eta}$ Ovoía) and the Divisible Essence

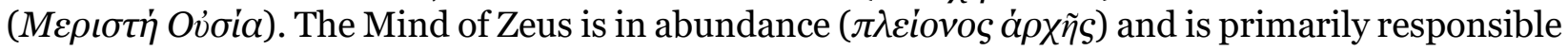
for the evolutionary course of the creation of the entire universe, because he it is who sets it in motion. Due to the original essence of Zeus, the process of Anamneses is set in motion, as it follows

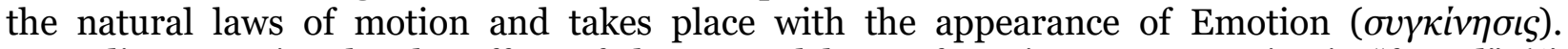
According to Aristotle, the effect of the natural laws of motion on memories is "forced" ( $\dot{\varepsilon} \xi$ $\dot{\alpha} v \alpha \dot{\gamma} \gamma \eta \varsigma$ ). The ancient term of Necessity (Anage) is considered (Charalampidis, 2018: 49) identical with the modern term of Entropy in physics, which is recognized as the driving force behind the creation of the universe. The Mind of Zeus, the original substance, is the first of the three substances which necessarily bears the effect of Need/Entropy, resulting in its movement. Then this Mind sets in motion the two qualities of memory. Entropy, then, is the pre-eminent driving force that moves our Mind, a fact absolutely necessary for our spiritual evolution (Charalampidis, 2018). These views of Aristotle seem to be confirmed by modern science. According to a very recent research in 2020 (Physics4u Weblog), our brain can produce consciousness as a side effect of the increasing entropy of the universe. That is, human consciousness emerges due to increasing universalist entropy.

\subsection{Athena}

If Zeus-Hades is the Mind of Zeus, that is, the driving force that sets in motion human consciousness, we understand why in the worship of Itonia his associate is Athena.

The very myth of her birth from the head of Zeus suggests that she is the one who comes from the supreme divine mind. If we accept that the noun "Theos" ( $\Theta \varepsilon o ́ s)$, the Greek word for God, comes from " $\theta \dot{\varepsilon} \omega$ " (theo) which means run (Charalampidis, 2018: 19), it could denote the perfectly evolved mind, which derives from the universal Mind of Zeus. Plato (Kratylos 407b) defines Athena as " $\dot{\eta} \theta$ covóa ćotiv aótr”", the one who comprehends (noousa) the divine (ta theia), the mind (noeses) of the god (imperative "a" - theos - noa, are the components of the name given by Polymeri 2018: 28). Although Plato's interpretation is characterized as para-etymological (Wikipedia, Athena), he nevertheless gives us the essence of the meaning of Athena's name, as well as the deeper meaning of mystical knowledge, for which Plato in many parts of his work gives us evidence and hints.

Athena is the goddess of Wisdom and Circumspection (Fronises). If we accept the view (Charalampidis, 2018: 24; 2019: 37-39) that the word "fronisi" indicates the direction ( $\varphi$ o $\alpha$ ) of the mind ( $v o v)$, then we realize that Athena is directly connected with free will; that means the choice of the direction of our mind.

Athena contributes to human mental and phsychic/emotional development. It offers both of the virtues that are necessary for the evolution of the mind: the mental virtue of Wisdom (accumulation of knowledge) and the moral, psychic virtue of Soundness of mind (Sofrosyne) that allows the development of free will, so that the human mind from "akon" ( $\ddot{\kappa} \kappa \omega v)$, which works only with the mental virtue of wisdom, to become "ekon" ( $\dot{\varepsilon} \kappa \omega v$ ), to function additionally with the 
accompaniment of the mental virtue of soundness of mind, with a developed free will. Mental virtue is taught, it is an object of learning, but moral virtue is cultivated through the mystic life and transmitted through tradition and culture (Charalampidis, 2019: 25-28, 30). Thus, we can explain the connection of Athena with the mystical cult, such as that of Itonia in the Boeotian Koroneia.

\subsection{Medusa-Perseas}

Although Medusa is absent from the "Thessalian" version of the myth -according to which Iodama is the goddess' sister who dies by the deity herself-, in the Boeotian cult of Itonia she plays a key role. In the variant of the myth that Pausanias follows, Iodama has become a priestess of Athena and is petrified by the head of the Gorgon Medusa. Her face was either embroidered on the tunic, or, according to other versions, depicted on the shield of the goddess, or even the goddess herself had the face of Medusa. The cap of Hades ( $" \delta \delta v \kappa v v \dot{\eta} v$ ), which Athena is represented as wearing on the cult statue of Agoracritus, is a characteristic symbol associated with Medusa.

Athena, along with Hermes, helped Perseus kill Medusa. After giving him all the necessary paraphernalia (the hat that made him invisible, winged sandals, gold sword, shiny shield and the magic bag that deactivated the properties of Medusa), Athena advised him, while beheading Medusa, to look into the shield reflecting the figure of the Gorgon in order to avoid her terrible face that has the force to turn people to stone. From the head of Medusa, cut off by Perseus, jumped the giant Chrysaor and Pegasus, the winged horse of Perseus. Athena put on Medusa's skin and put the gorgoneion, that is, the apotropaic mask of Medusa's head, on her shield for protection (Kerenyi, 1966: 60; Christopoulos \& Kakridis, 1986, III: 182-4).

This myth seems to have a special significance in the region of Helikon. According to the legend, Pegasus, the winged horse of Perseus, left his footprints on the Mount Helicon and from them jumped the mountain spring of Ippokrene (Іллок horse (Strabo 8.6.21, Christopoulos \& Kakridis, 1986, III: 252). This spring, which as we have seen is connected by Strabo with the Thracian worship, according to one view, has been identifiable in the place "Kryo Pigadi" above the valley of the Muses (Douson, 2010: 92). Additionally, above the sanctuary of Itonia, on the slopes of Helikon that reach the highest peak of Paliovouna, in the place where the settlement of Koukoura / Agia Anna is today (Figure 4), there was the ancient village called "Hippotai" (Fossey, 1988: 339-340; Farinetti, 2011: 23, no 31), whose name derived from "Hippos", meaning "horse".

According to the interpretive approach of Charalambides (2020), the three Graies (the three sisters of Gorgones), which Perseus had to face first in order to meet Medusa (Kerenyi, 1966: 59), symbolize mortality, material corporeality. In this situation, according to the Platonic theory (Plato, Phaedrus) for the three parts of the soul (Charalampidis, 2019: 59), out of the three parts only 2 parts work, but they are also bipolar, that is, when one works the other is deactivated, as well as in the state of the unconscious man. This symbolizes the one eye and the one tooth shared by the Graies, which is why they are slow-witted "vradinoes", in contrast to their sisters the Gorgons who, as their name implies (gorgo = fast), are quick-witted "tachinoes" and symbolize immortality. But our immortality is covered by the head of Medusa the Gorgon which symbolizes the selfishness and evil that each of us has inside them, which is capable of killing us, of petrifying us, as happened with Iodama.

Perseus in order to conquer immortality and become the ruler of himself, wants, according to the platonic theory about the soul's tripartite (trimereia), to activate the third part of his soul, (which named Logistikon/Voulitikon by Plato and Aristotle respectively and I translate as accounting and volitional). That means that Perseus had to coordinate the two other parts of 
his soul (named as Epithimitikon and Thymoeides, which I translate respectively as desirable and passion-thymoid). This presupposes that Medusa must be beheaded, that is, the selfishness and evil that every person hides inside, because only in this way will they have a crisis and will rise to higher levels. Therefore, Perseus, in his attempt to kill Gorgon-Medusa, completes the initiation process of the Technosis of the Mind, unites the two poles of his memory, the Mind and the Soul, puts the two contradictory parts of his soul under control, and becomes master of himself (Charalampidis, 2020). This is symbolized by the fact that he rides the winged horse Pegasus. That is why he is under the protection of the equestrian "Hippelateira" Athena (Orphic Hymn to Athena), who knows how tame the two "aloga" (lacking logic) parts of the soul. The priestess Iodama, however, had not evolved to this level.

In some myths Medusa is also associated with Persephone and Gorgon's head appears in the Underworld as her self-defense (Kerenyi, 1996: 60). Accordingly, it also functions as a symbol of human terror in front of death, when a mortal is not ready to face it.

Medusa, Cerberus, the serpent, as well as other magical objects that have monstrous deterrent power and are used by Athena for shielding, have been associated with the original, preOlympic chthonic attribute of Athena as goddess of the Underworld (Christopoulos \& Kakridis, vol. 1: 228-232, vol. 3: 105). Thus, Medusa has the power to deter, to protect the world of the goddess from those who want to invade it, from those who do not meet the conditions to become members of it, the uninitiated. Medusa defends the sacred space of knowledge possessed by the goddess, either as Athena or Persephone.

But Athena, with the beheading of Medusa, gained an extra terrible power, the one that had the blood of the Gorgon (Apoll., 3.120): what flowed from the left could kill, while what flowed from the right could heal, even to raise the dead.

According to the principle that only the one who causes the trauma can heal it $(\dot{o}$

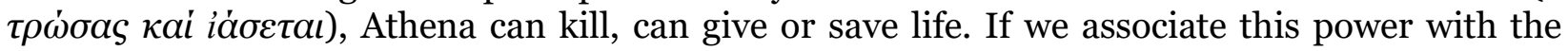
human soul we understand the deeper symbolism of the myth: only a person who knows the incurable wounds "teilephia traumata" of their soul, which their incarnate soul has unknowingly caused, can heal them (Charalampidis, 2018). The healed soul is considered (Charalampidis, 2018: 146) to be symbolized by the golden ram associated with Lafistios Zeus, as well as the golden fleece, which was sought by the Argonauts. It has been argued that from the original nature of Athena as goddess of the Underworld derive the majority of her other qualities, as a deity of vegetation, warfare and health (Christopoulos \& Kakridis, 1986, I: 231). Because of Medusa, I believe that the Boeotian Itonia Athena is a goddess of health to the same degree as she is a goddess of war

Medusa symbolizes the power of the goddess to transform the material world by incorporating its menacing dimensions and modifying the direction of its movement. With the blood of Medusa Gorgon, Athena acquired the supplies and the power to heal those in need. Those who try to heal the "teilephia traumata" and tame that parts of their soul which have no logic (aloga).

\subsection{Athena Promachos and the stages of human evolution}

In this difficult course of human, Athena supports as Promachos. Athena had the epithet Promachos because she helped people in all kinds of battles and supported them in their difficult times in general (Christopoulos \& Kakridis, 1986, II: 100; Burkert, 1993: 430-431). That is why she is the goddess who above all supports heroes. He is next to Perseus, as well as to Herakles, Theseus, Odysseus, Jason and the Argonauts, Velerefontis, but also to every person who seeks to give his battles and perform his feats in order to be able to coordinate the three parts of his soul and to become master of himself, to ascend to higher levels and to apply the concept of Justice (Dikaio). 
Ancient Greek philosophy recognizes three stages of human evolution, which are related to the three stages of Technosis of mind according to Aristotle: the Dipod or Andrapodos, the Man and the Self-Man. In the first stage, that of Dipodos, or Andrapodos according to Pythagoras, the human mind is unconscienced and "akon", it works without its will, automatically. Because he is in an instinctive state, he constantly produces unconscious and unconnected thoughts, without guidance. That is why he is undeveloped, without making any substantial progress, as he lacks any form of moral virtue.

At this stage man must, as Aristotle emphasizes, learn to control his unbridled imagination, which is an inherent element of the functioning of his brain, his mental memory, and the illusions caused by it, as the two these elements do not allow him to make an objective judgment. That is why he is taught, he learns Wisdom (Sofia), Circumspection (Fronisi) and Prudence (Synesi). He acquires knowledge, techniques and practices which he learns to manage based on his logic, in order to decide the most appropriate way to use them. However, at this stage man has not reached the point of being master of himself, nor has he conquered free will, on the contrary he is a prisoner of his fantasies and illusions, leaving his logic to lead him without a rudder. The memory of his soul is lethargic. Man has mental ability, but is characterized by

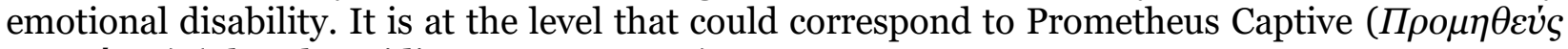
$\Delta \varepsilon \sigma \mu \omega \dot{\tau} \eta$ ) (Charalampidis, 2018, 2019: 40).

In the second stage of evolution, man, according to Aristotle, is called upon to identify the bad habits (exeis/है $\xi \varepsilon \iota s$ ) and the fears that have been caused by bad experiences. These elements, together with all the negative consequences that they imply, according to Aristotle, are described as seals that have been imprinted, engraved on the malleable material of our soul, shaping our character (from engrave and Hera, which means soul). In order man be able to face the bad "exeis" and change his character, he must deal with the nine Muses, that is, the arts that they represent, and cultivate through initiation the twelve moral virtues (Nemesis, Andreia, Eutrapelia, Aidos, Magaloprepeia, Sofrosini, Aletheia, Eleftheriotis, Praotis, Philotimia, Megalopsychia, Filia), in order to enable him to exercise Justice and to be Just.

At this stage man gains control of himself. Logic cooperates with morality and man conquers Free Will. This is what marks the transition from the first to the second stage. The acquisition of mental and psychic ability is the precondition for releasing man from the program of the autopilot of fate in order to become master of himself. This is achieved through the psychic function of Memory, which makes it possible to access the memory of the soul, the recollection of its "teilephia traumata" from previous lives. A painful and difficult process, which is achieved initially through the five senses, while then, as Aristotle implies, the senses of far-hearingness / in-hearing (Diakoe) and far-sightness/ insight (Diorasi) are activated. This stage can be assigned

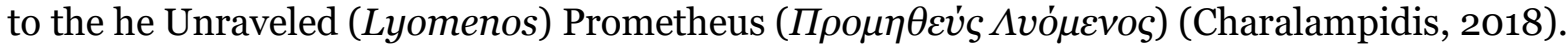

In the third stage of the Self-man (Autanthropos), man achieves his self-realization, the completion of his human destiny and reaches the level of assimilation with God. This is made possible through the psychic function of Memory which allows the transfer and recording of all, the bad habits (exeis) and the psychic traumas that they have caused, in his present mental memory, in order to heal them with the help of the already conquered logic and ethics.

This stage can be matched to the level of Prometheus Pyrphorus ( $\Pi \rho \mu_{\mu} \theta \varepsilon \dot{v} \varsigma$ $\left.\Pi v \rho \varphi \rho_{\rho} \rho \varsigma\right)$. The union of mind and soul has been achieved. The soul has been healed from its "teilephia traumata", it has regained its health and strength. It has been achieved what Apollo's Delphic motto defines as "knowing ones' shelf" and was a prominent goal of ancient Greek philosophy and the initiation rite of the mystical cults (Charalampidis, 2018). It is the stage conquered by the heroes, whose souls have become powerfull, strong (alkimos) (Charalampidis, 2019: 32). 


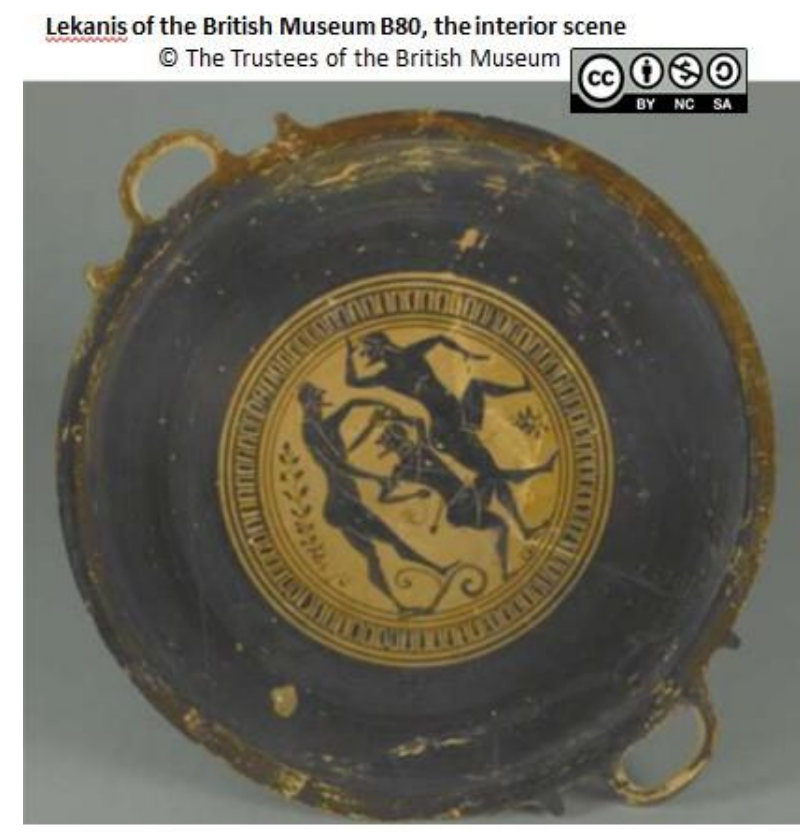

Figure 7.

I believe that this process is symbolized by the interior representation of the B8o lekanis of the British Museum. The male figure that runs is the unconscious baser self, the one that is separated from his higher self. The higher self is represented by the other figure who is standing calmy: this is the one who has managed to control the "aloga" parts of his soul, the desire, the fears, the egoism, the illusions and so on. These elements is symbolised by the sword as they can become very dangerous when they are out of control. The soul is therefore represented by the small figure that carries the sword, which the calm conscious figure has captured by the shoulder controlling it. The visual contact which have the running figures with the standing man underlines the bond between the lower and higher self, between the soul and the mind.

Therefore, as Aristotle teaches us, the question of memory predominates in terms of our raison d'être and the way our psyche evolves, because it is connected with consciousness, a deeper understanding of ourselves, of who we are and how we act. Modern science also recognizes three types of human syneideses: the individual, the social and the global (Danezis, 2017b: 39.10). The currently established term "syneideses" (in English translated as consciousness and

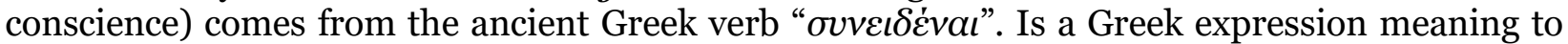
share $(\operatorname{syn}=\sigma v v)$ knowledge (eidenai $=\varepsilon i \delta \dot{\varepsilon} v \alpha$ ) ) with oneself $(\dot{\varepsilon} \alpha v \tau \tilde{\omega})$, as stated by the dative personal pronoun that accompanies the verb (Liddell \& Scott 1994: 1704). It, therefore, refers (Sorabji, 2015: 18-22) to knowledge shared with oneself, as if one has been divided in two. According to Danezis (2017b: 25.33-34.21) it is the path to the Truth that refers to us, the union ( $\sigma u v-\dot{\varepsilon} v \omega \sigma \eta)$ of Knowledge's information, of what has already happened.

\subsection{Itonia and Iodama}

Itonia's relationship with the Iodama has analogies with other mythical pairs of mortals and gods and in these relationships it is considered (Kerenyi, 1966: 122) that we see the two sides of the same goddess with different names. It has been stated (Burkert, 1993; 394-5, 422; Schachter, 1981, vol. 1: 120) that Iodama, like other mortals, is presented as the mortal alter ego of the goddess, but the destruction by God seems to be a divine predetermination and then the victim is honored in worship as a god. Thus Iodama "lives" as an altar of Athena, bearing the eternal fire. The mortal who dies in this way remains in the divine realm as a dark reflection of the 
god. Another interpretive point of view (Yiovi, 2017) advances this train of thought and relates it to the journey in search of the self, the eternal journey of "knowing oneself". In this journey of selfknowledge, what is required is the unquenchable fire of knowledge and that is why the fire of the mind must be rekindled daily, as in the altar of Iodama. Humans, as reflections of the gods, are perceived as their mortal look-alikes who remain in the divine realm and seek fire to illuminate all their darkness. Starting from the bases laid down by the above views, my own interpretation goes a little further.

Cunning suggests that the name Iodama (from the pronoun "iolos", meaning "autos" and the verb " $\delta \dot{\alpha} \mu v v \mu$ ") is the equivalent of "Autodama", which means "the one who controls herself (Lalonde, 2019: 136-7, sb. 197). More precisely, according to my view Iodama denotes the unstructured soul that is finally tamed (from "Ios" (iós) which means fluid, liquid and "dameo/dammymi" ( $\delta \alpha \mu \dot{\varepsilon} \omega / \delta \alpha \dot{\mu} \nu v u \iota)$ which means tame, see Stamatakou, 1972: 470). In other words, it is the incarnate soul that has forgotten its origin and its possibilities, it is our lower self that functions only with the memory of the brain, logic, it is the soul that is trapped in the eternal cycle of reincarnations until it manages to heal. That is why in the representation of the vase B.80 on the altar, which is identified with Iodama, stands a bird, which is considered to be a symbol of the soul.

In the founding myth of Itonia we have two variants of Iodama, as a sister and as a priestess of the goddess Athena. The first version I consider to symbolize the relationship between the upper and lower self, where the sister Jodama is the lower self that dies and is reincarnated. In the second version, where Jodama has evolved into a priestess of the goddess who dies facing Medusa, symbolizes the uninitiated, the unconscious facing her lower self and petrified to be reborn by initiating.

Itonia, on the other hand, is our higher self that functions with emotional intelligence and preserves the memory of the soul, the universe, the total knowledge we have acquired in all our reincarnations. In this soul are engraved all the wounds that the incarnate self has caused with its ignorance and as we have seen only the one who caused them can heal them, purify the soul, heal it in order to be renewed. Iodama asks for fire every year to be reincarnated, but also to be purified. The purpose of each incarnation (Charalampidis, 2019) is the mind to become conscious, to acquire the ability to intervene and to determine its course according to its mental and psychic needs.

Iodama and Itonia, then, are the two aspects of the same self, that represent the different qualities of memory and consciousness. Only the flame of knowledge (altar of Iodama) will allow the union of the two memories, the healing of the wounds of the soul and its deification. The unhealed soul (Iodama) is constantly seeking incarnation, because only through it can its healing take place, if the embodied self (the rebirth of Jodama) remembers the previous incarnations and the mistakes it has made in them and corrected them. Each time she dies, returns to the kingdom of Hades waiting for its next rebirth.

The name of Itonia, etymologically, comes from the root "-it" of the verb "eimi" ( $\varepsilon \tilde{\mu} \mu$ ), as Papachatzis observes, but in my opinion, it is not related to the war, but mainly refers to a

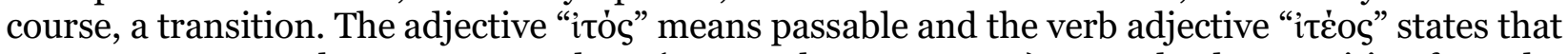
one must go somewhere, get somewhere (Stamatakou, 1972: 417). To make the transition from the state of ignorance, of the unconscious, to the state of consciousness and knowledge of the Truth found in the realm of Hades or Pluto, which is considered (Charalampidis, 2018) to symbolize the realm of the wealth of ideas, the universal wisdom.

Athena as goddess of wisdom, as a Tritogeneia (representing the union of the desirable / epithimitikon, the passion-thymoid / thymoeides and the accounting / logistikon or volitional / voulitikon part of the soul) is the ruler in this kingdom, assistant of the Orphic Zeus-Hades, who dies and reborn every year refreshed to sit on his throne. Person must be led to this universal 
wisdom in order to remember the memory of his soul and to truly know himself, as dictate the Delphic order of knowing oneself (gnothi sauton) so that he can be reborn renewed and be in harmony with the universal spirit of Zeus. There only Itonia can lead him and only Athena, the one that emanates from the universal mind, can support him.

The process is painful, because the soul with its incarnation forgets all the wisdom it has acquired from its previous lives. In the chthonic kingdom of knowledge the ordinary person, the uninitiated, has no access, as it is guarded by the terrible Cerberus and Medusa Gorgon. Contact with the memory of our soul is not easy. Cerberus symbolizes (Charalampidis, 2018: 138) exactly what prevents the memory of the mind from meeting the memory of the soul.

This sacred space is inaccessible to the living and the common mortals. This path can be crossed only by an initiate with the help of Athena. Such were Orpheus, Odysseus, Herakles who managed to descend to the nether world and returned victorious. Athena supports and helps heroes who have managed to gain control of their minds, those who have strategy and intelligence as expressions of free will.

\subsection{Kerveros, Heracles, Charops and Palaimon}

In the neighboring sanctuary of Herakles Charops, by the sacred river Falaros, the hero returns victorious from the descent to Hades. He defeated Cerberus, the obstacles that did not allow him to unite with the memory of his soul. He managed to heal his wounds and returns liberated, happy, victorious, renewed. This is also stated by the adjectives attributed to him. The name "Charops" (or "Charopas") has been proposed denoting the one whose eyes sparkle with savagery, and is associated (Papadakis, 1916) with Charon (another name of Hades), he who ferries the souls to the underworld. More likely, according to my opinion, means him who has eyes full of joy " $\dot{\varepsilon} \dot{\varepsilon} \chi \omega \nu o \varphi \theta \alpha \lambda \mu o v ́ \varsigma \pi \lambda \dot{\eta} \rho \varepsilon \iota \varsigma \chi \alpha \rho \alpha \dot{\varsigma}$ " (from chara = joy and opa = optic) (see Stamatakou, 1972: 1103). It therefore describes the one whose soul has been opened to light and joy, the one who has gained the wisdom of Athena, as protected by Itonia: the free individual who has broken the bonds of materiality and has gained universal wisdom. The adjective "Kallinikos" also denotes the gloriously ( $\left.\kappa \alpha \lambda \eta^{\prime}\right)$ triumphant (vi $\left.\kappa \eta\right)$ (Stamatakou, 1972: 489), the one who has achieved the victory of the good, the conquest of knowing themselves ( $\gamma v \dot{\omega} \theta \mathrm{\imath}$ oavtóv).

The epithet "Palaimon", attributed to Herakles, connects us with the Dionysian cycle, through the myths of Orchomenos and Thebes. Palaimon is the other name of Melikertes, the son of Athamas and Ino, who is sister of Semele and aunt of Dionysus. Because she took care of the baby of her lightning-stricken sister, Hera punished her and her husband with madness, and so Athamas devoured his son Leagros, while Ino fell into the sea with her son Melikertes. Ino was transformed into the sea deity Leukothea (white goddess), worshiped throughout the Mediterranean (Burkert, 1993: 363), and Melikertes into Palaimon, who protected sailors (Kerenyi, 1966: 249, Christopoulos \& Kakridis, 1986, III: 74, 122). Palaimon is considered to appear as another Dionysus (Kerenyi 1966:249). In the Isthmus of Corinth, where his dead body came out, he was honored as a hero. It is a cult of a child hero with epitaph ceremonies, games of an initiatory nature, and possibly a night-time mystical ritual (Kerenyi, 1966; Burkert, 1993: 2367, 295, 431).

In Boeotian Koroneia the combination of Palaimon with Herakles, who succeeded in descending to Hades, is not accidental. Therefore, Herakles Palaimon, as well as Pangrateios perhaps, seems to symbolize the reborn child within us, the reborn soul after the testing of its selfknowledge, after the healing of its "teilephia traumata". The soul is incorruptible and immortal, so the goal of initiation is to develop a healthy soul. We now understand why Charops or Palaimon Herakles is the protector of freed slaves, who were dedicated to him. He is a terrible god because enslavement of all kinds is cruel and brutal. But he is also a comforting god, because he promises 
and gives freedom, with the help of the neighboring Athena Itonia, under whose protection he is. And it is because of Itonia that in the service of Herakles Charops we find a priestess instead of a priest.

The interpretive framework presented above allows an interpretation of the meaning of the word "Nike" engraved on the Hermetic column. It also helps us understand why in some vases, related to the worship of Itonia in Koroneia, Athena is depicted conversing with Hermes, the "psychopompos", the one who accompanies the souls to Hades.

\section{Conclusions}

Boeotian Itonia seems to combine many qualities. In her common worship, the one that was open, she has a fertility aspect as a deity of vegetation, who simultaneously, as Promachos, helps and protects anyone in need and especially the fighters, the warriors. The festivities and the pleasant atmosphere they created were, moreover, a prerequisite for the inception of the initiation process (Charalampidis, 2018). In her mystical cult, which received the influences of Orphism, Itonia possesses the universal wisdom of Zeus hidden in the kingdom of Hades, so only she can lead the initiator and seeker of Truth to this knowledge. Athena as a goddess of circumspection, who controls the direction of the mind, and as a goddess who comes directly from the universal mind of Zeus is the one who can guide people how to harmonize their mental with their psychic memory and to dominate the irrational (aloga) parts of their soul. Itonia is associated with the memory of the soul. She possesses the knowledge of how the soul will avoid the fate of Sisyphus and will move from the unconscious to the conscious level. The purpose of the mystery worship was for the faithful to acquire, through initiation rites, this knowledge of self-consciousness via contact with the memories of his soul. That is why the founders of its cult are connected with the family line of Prometheus.

The concept of conscience is an important aspect of human existence, which, although it has been employed in many scientific disciplines, is considered nowadays to remain largely unknown. It is usually perceived as an almost transcendental aspect of the human mind. The degree of integration of Aristotelian mental and psychic memory is now defined (Vythoulkas \& Muresanu, 2014) as the "degree" or quality of conscience, which indicates how close the individual is to the realization of Truth, and is considered to be determined by two factors: (a) the evaluation of information received, and (b) the free will of the individual to decide whether or not to abandon his human instincts. It is argued that the more human beings succeed in dominating their passions and basic instincts, the more their conscience evolves and with an inevitable rule the common good is placed above private interest. However, modern humanity is governed by mental ease but also by psychic distress, and either it is not interested or unaware how to upgrade the quality of "conscience" by coordinating the two qualities of memory, as was done in the mystic worship of Itonia.

Carl Yung has pointed out that the spirit of culture can only be renewed with a change in the attitude of the individual. The goal of cultural progress in ancient Greece was the development of individuals from the state of Andrapodo to that of Autoanthropo, the human being as an integrated entity, with the acquisition of the supreme moral virtue of Justice. The underlying view was that a lack of morality and justice destroyed any notion of culture. How inconsistent is modern rationalization society with these teachings?

\section{Acknowledgements}

I wish to thank Hamish Forbes from the University of Nottingham for the proof editing in English translation. I also thank the management of the British Museum for permitting 
me the Creative Commons Licence for vase B80, Dr. Emeri Farinetti for the permission of using the archaeological map of ancient Koroneiake, the archaeologist Spyropoulos Theodoros and the director of Public Library of Leivadia Leonidas Diamantis, for their help in getting me access to difficult to- find publications during the coronavirus period, and finally my friend Joanna Michali for her useful remarks.

This research did not receive any specific grant from funding agencies in the public commercial, or not-for-profit sectors.

The author declares no competing interests.

\section{References}

Academic Dictionary of Greek. From https://greek greek.enacademic.com/.

Bintliff, J., Slapsak, B., Noordervliet, B., van Zwienen J., \& Verweij, J. (2009). The Leiden-Ljubljana Ancient Cities of Boeotia Project, Summer 2007 - Spring 2008. Journal of The Netherlands Institute at Athens, Pharos, 2009 (pp. 17-42).

Bintliff, J., Noordervliet, B., Van Zwienen, J., Wilkinson, K., Slapsak, B., Stissi, V., Piccoli, C., \& Vionis, A. (2013). The Leiden-Ljubljana ancient cities of Boeotia Project, Season 2010-2012. Journal of The Netherlands Institute at Athens, Pharos 19(2), 1-34.

Bloch, D. (2007). Aristotle on memory and recollection, Philosophia Antiqua, Vol. 110. Leiden-Boston: Brill.

British Museum B.80. Registration Number 1879, 1004, 1:

https://www.britishmuseum.org/collection/object/G 1879-1004-1. See also Lexicum Iconograficum Mythologie Classic (LIMC), the exterior scene of the vase:

https://weblimc.org/page/monument/2112767. Classical art Research Center, University of Oxford, the interior scene:

https://www.beazley.ox.ac.uk/XDB/ASP/recordDetailsLarge.asp?recordCount $=1 \&$ id $=\{63$ D9 0283-0411-466E-932D-9A35B4D5616D \}\&returnPage=\&start.

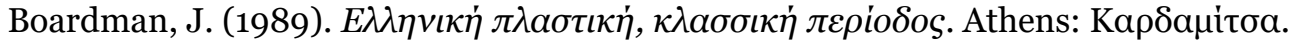

Bonnescere, P. (2003). "Trophonius of Levadea" mystery aspects of an oracular cult in Boeotia. In M. B. Cosmopoulos (Ed.), Greek Mysteries, The archaeology and ritual of ancient Greek secret cults (pp. 169-192). London and New York: Routledge.

https://books.google.gr/books?id=P9aAAgAAQBAJ\&printsec=frontcover\&hl=el\#v=onepag\& $\mathrm{q} \& \mathrm{f}=$ false.

Buck, J. R. (1979). A History of Boeotia. University of Alberta Press.

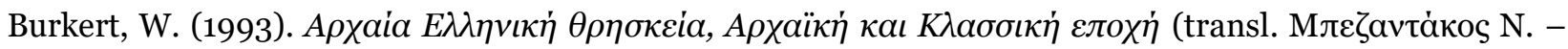

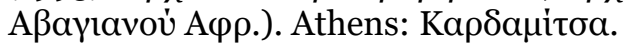

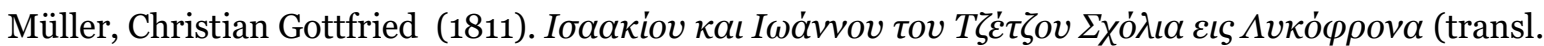
Joseph Juste Scaliger). Leipzig: Sumtibus F.C.G. Vogelii (google books)

https://books.google.gr/books?id=7AlGAAAAMAAJ\&printsec=frontcover\&redir $\quad \mathrm{esc}=\mathrm{y} \# \mathrm{v}=\mathbf{0}$ nepage\&q\&f=false.

Cook, A. B. (1964). Zeus, A study in Ancient religion, vol. I. New York: Biblo and Tannen.

Cook A. B. (1965). Zeus, A study in Ancient religion, vol. II. New York: Biblo and Tannen. 
E. G. Goula - The Cult of Itonia Athena and the Human Conscience

Farinetti, E. (2011). Boeotian landscapes: a GIS-based study for the reconstruction and interpretation of the archaeological datasets of ancient Boeotia. Oxford: Archaeopres (Dissertation for $\mathrm{PhD}$, Leiden University, Belgium, 2009. https://openaccess.leidenuniv.nl/handle/1887/14500).

Fossey, J. M. (1988). Topography and population of ancient Boiotia (Vol. 1). Chicago: Ares Publishers.

Graninger, D. (2010). Cult and Koinon in Hellenistic Thessaly. Brill Studies in Greek and Roman Epigraphy. Leiden/Boston: Brill.

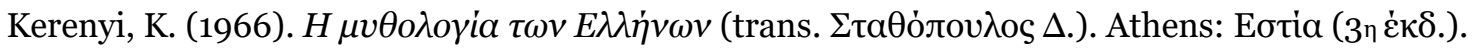

King, R. A. H. (2009). Aristotle and Plotinus on Memory. Quellen und Studien zur Philosophie, Band 94. Berlin - New York: Walter de Gruyter.

Lalonde, G. V. (2019). Athena Itonia: Geography and Meaning of an Ancient Greek War Goddess. Religion in the Graeco-Roman World, Vol. 191. Brill: https://1lib.eu/book/5435511/63dd1f.

Lauffer, S. (1986). Kopais I. Untersuchungen zur historisschen Landeskunde Mittelgriechenlands. Frankfurt: P. Lang.

Leake, W. M. (1835). Travels in Northern Greece, Vol. II. London.

Liddell, H. G., \& Scott, R. (1994). Greek - English Lexicon. Oxford: Clarendon Press.

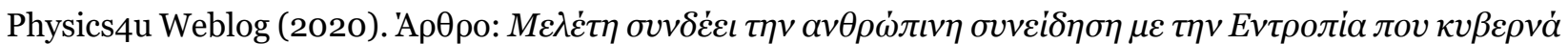

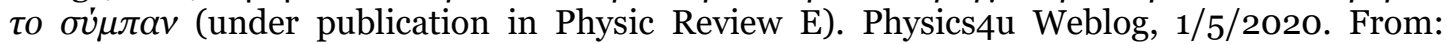
https://physics4u.wordpress.com/2020/05/01/\%CE\%BC\%CE\%B5\%CE\%BB\%CE\%AD\%CF\% 84\%CE\%B7-\%CF\%83\%CF\%85\%CE\%BD\%CE\%B4\%CE\%AD\%CE\%B5\%CE\%B9\%CF\% $84 \% \mathrm{CE} \% \mathrm{~B} 7 \% \mathrm{CE} \% \mathrm{BD}-$ \%CE\%B1\%CE\%BD\%CE\%B8\%CF\%81\%CF\%8E\%CF\%80\%CE\%B9\%CE\%BD\%CE\%B7\%СF\%83\%CF\%85\%CE\%BD\%CE\%B5\%CE\%AF\%CE\%B4\%CE\%B7/.

Pritchett, W. K. (1969). Studies in Ancient Greek topography, part II. Berkeley \& Los Angeles: Battlefields.

Schachter, A. (1981). The cults of Boiotia, vol. 1: Acheloos to Hera. Bulletin Supplement (University of London, Institute of Classical Studies), 38(1). Oxford Journals: Oxford University Press.

Schachter, A. (1986). The cults of Boiotia, vol. 2: Herakles to Poseidon. Bulletin Supplement (University of London, Institute of Classical Studies), 38(2). Oxford Journals: Oxford University Press.

Schachter, A. (1994). The cults of Boiotia, vol. 3: Potnia to Zeus. Bulletin Supplement (University of London, Institute of Classical Studies), 38(3). Oxford Journals: Oxford University Press.

Schacter, A. (2003). Evolutions of a mystery cult, The Theban Kabiroi. In Michael B. Cosmopoulos (Ed.), Greek mysteries, The archaeology and ritual of ancient Greek secret cults (pp. 112-142). London and New York: Routledge. https://books.google.gr/books?id=P9aAAgAAQBAJ\&printsec=frontcover\&hl=el \#v=onepage \&q\&f=false.

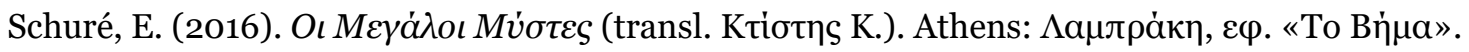

Sorabji, R. (1972). Aristotle on Memory. Boston Public Library: Brown University Press.

Sorabji, R. (2015). Moral Conscience through the Ages. Fifth century B.C.E to the present. Oxford University Press. Open Journal for Studies in History, 2020, 3(2), 47-72.

Tsakos, K., \& Viglaki-Sofianou, M. (2012). Samos the Archaeological Museums. Athens: J. S. Latsis, Public Benefit Publication.

Vythoulkas, G., \& Muresanu, D. F. (2014). Conscience and consciousness: A definition. Journal of Medicine and Life, 25/3/2014, published online: https://www.ncbi.nlm.nih.gov/pmc/articles/PMC3956087/. 
References in Greek

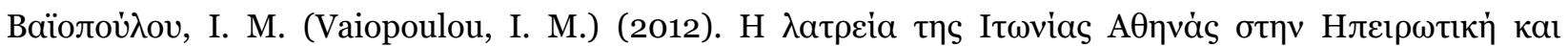

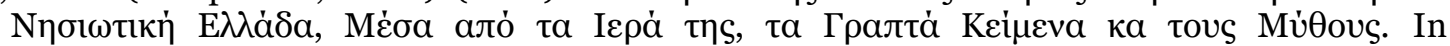
Stampolidis N.- Kanta A.- Giannikouri A (Eds.), Athanasia, The earthly, the celestial and the underworld in the early Iron Age (pp. 153-160), International Archaeological Conference, Rhodes 28-31 May 2019. Heraklion: University of Crete, Ministry of Culture, Mediterranean

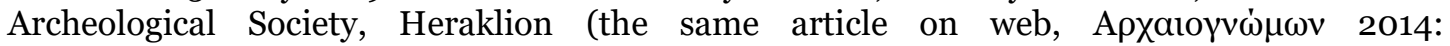
http://ellinondiktyo.blogspot.com/2014/o4/blog-post 20.html).

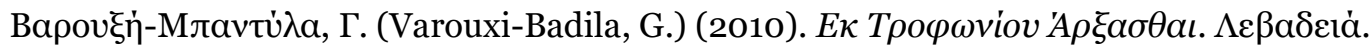

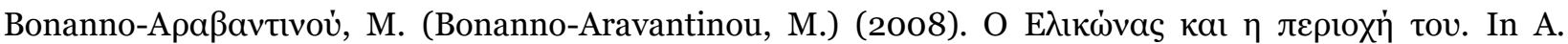

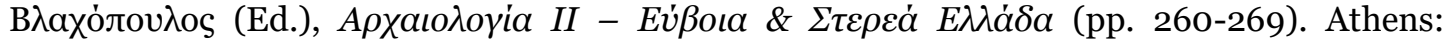

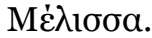

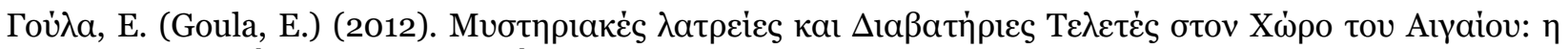

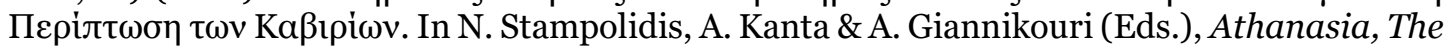
earthly, the celestial and the underworld in the early Iron Age (pp. 161-176), International Archaeological Conference, Rhodes 28-31 May 2019. Heraklion: University of Crete, Ministry of Culture, Mediterranean Archeological Society.

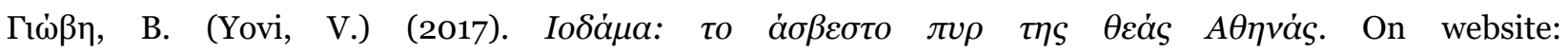
http://mythikianazitisi.blogspot.com/2017/08/blog-post 22.html.

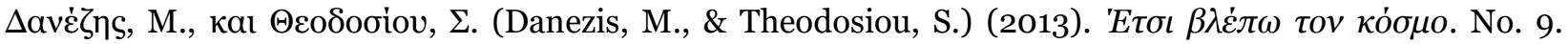
14/9/2013. In website: https://www.youtube.com/watch?v=MV3lgvMvgEs.

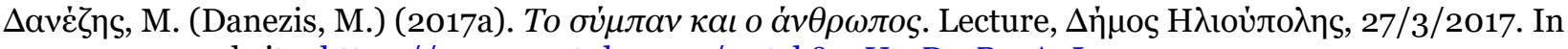
website: https://www.youtube.com/watch?v=V7aDmB7yAuI.

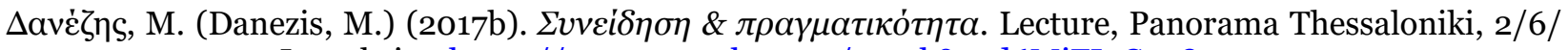
2017. In website: https://www.youtube.com/watch?v=d6MjFIqCop8.

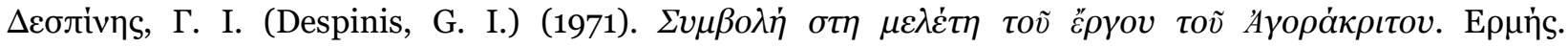

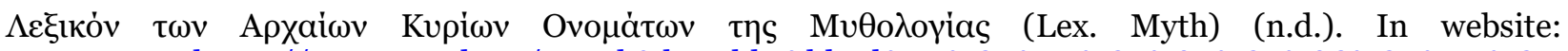
https://www.google.gr/search?tbm=bks\&hl=el\&q=\%CE\%B1\%CF\%80\%CF\%8C\%CE\%B3\%CE \%BF\%CE\%BD\%CE\%BF\%CE\%B9+\%CF\%84\%CE\%BF\%CF\%85+\%CE\%A3\%CE\%AF\%CF\%83 \%CF\% $85 \% \mathrm{CF} \% 86 \% \mathrm{CE} \% \mathrm{BF} \% \mathrm{CF} \% 85$.

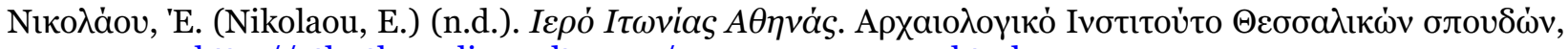
http://atlasthessalias.culture.gr/-----------------2.html.

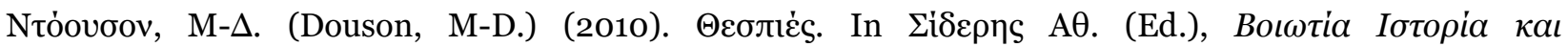

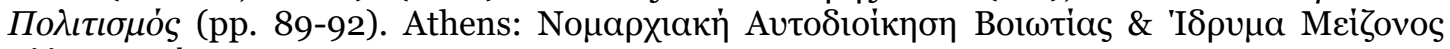

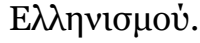

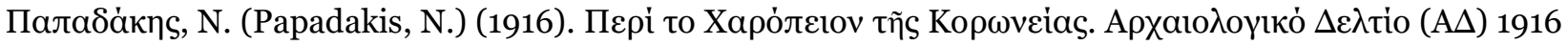
(pp. 217 on).

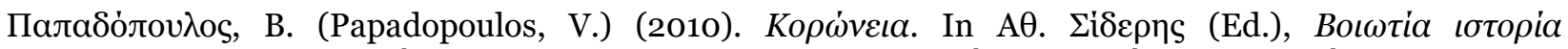

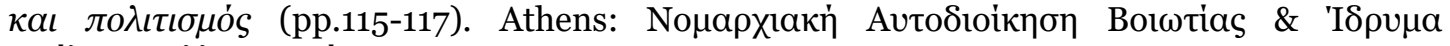

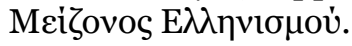

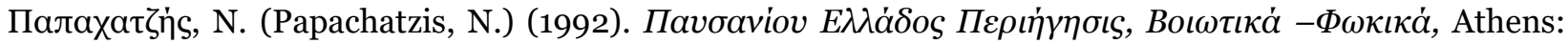

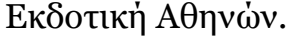




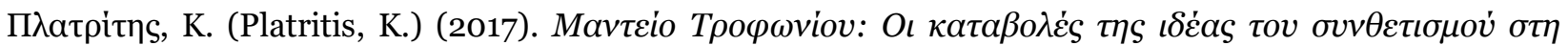

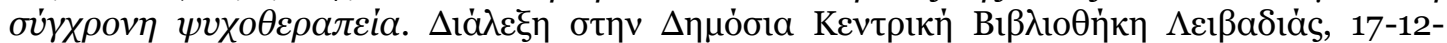
2017. In web: https://www.youtube.com/watch?v=n6Y4mlKgj6o\&feature=emb logo.

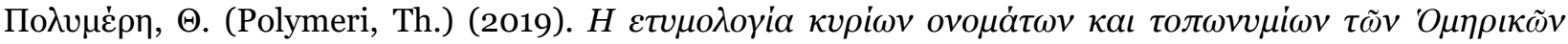

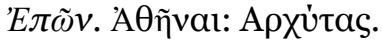

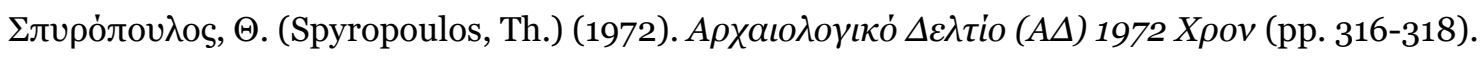

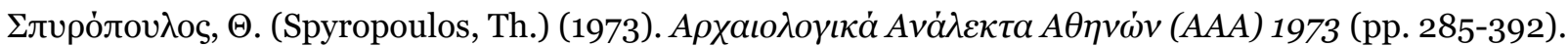

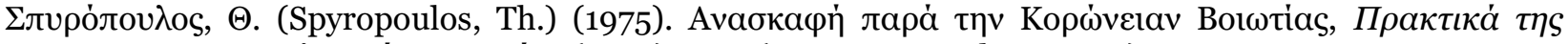

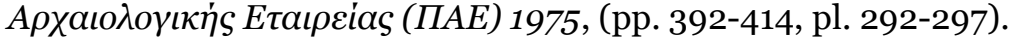

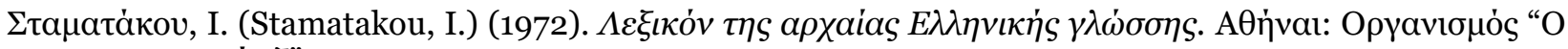
Фoivi $\xi "$.

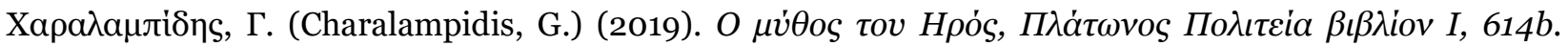

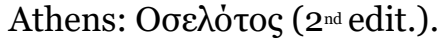

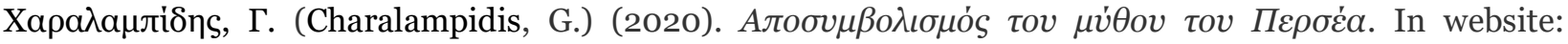
https://www.youtube.com/watch?v=PCKHSgp6Mn4.

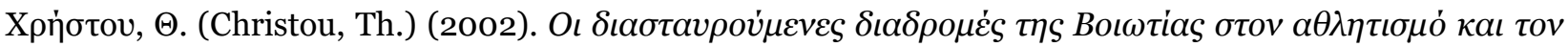

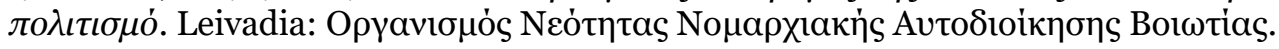

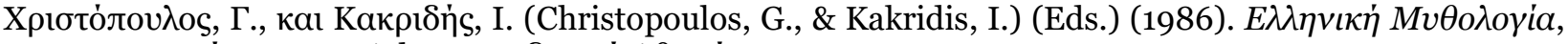

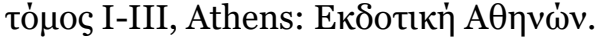

